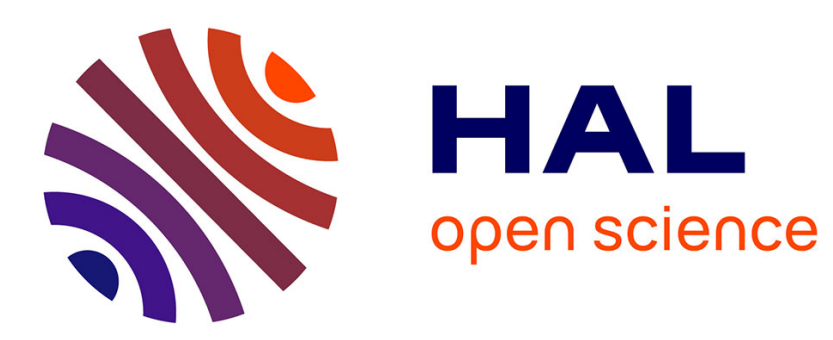

\title{
On the structural and magnetic properties of the ternary silicides Ce6M1.67Si3 $(\mathrm{M}=\mathrm{Co}, \mathrm{Ni})$ and Ce5Ni1.85Si3
}

Etienne Gaudin, Bernard Chevalier

\section{To cite this version:}

Etienne Gaudin, Bernard Chevalier. On the structural and magnetic properties of the ternary silicides Ce6M1.67Si3 (M = Co, Ni) and Ce5Ni1.85Si3. Journal of Solid State Chemistry, 2007, 180, pp.13971409. 10.1016/j.jssc.2007.01.030 . hal-00143700

\section{HAL Id: hal-00143700 https://hal.science/hal-00143700}

Submitted on 26 Apr 2007

HAL is a multi-disciplinary open access archive for the deposit and dissemination of scientific research documents, whether they are published or not. The documents may come from teaching and research institutions in France or abroad, or from public or private research centers.
L'archive ouverte pluridisciplinaire HAL, est destinée au dépôt et à la diffusion de documents scientifiques de niveau recherche, publiés ou non, émanant des établissements d'enseignement et de recherche français ou étrangers, des laboratoires publics ou privés. 


\title{
On the structural and magnetic properties of the ternary silicides $\mathrm{Ce}_{6} \mathrm{M}_{1.67} \mathrm{Si}_{3}(\mathrm{M}=\mathrm{Co}, \mathrm{Ni})$ and $\mathrm{Ce}_{5} \mathrm{Ni}_{1.85} \mathrm{Si}_{3}$
}

\author{
E. Gaudin*, B. Chevalier \\ Institut de Chimie de la Matière Condensée de Bordeaux (ICMCB), CNRS [UPR 9048], \\ Université Bordeaux 1, 87 Avenue du Docteur A. Schweitzer, 33608 Pessac Cedex, France.
}

* Corresponding author: gaudin@icmcb-bordeaux.cnrs.fr

\begin{abstract}
Contrary to that reported previously, the ternary silicide " $\mathrm{Ce}_{6} \mathrm{Ni}_{2} \mathrm{Si}_{3}$ " does not exist. The melting of this alloy, followed or not by an annealing, leads to the existence of the two new ternary compounds, $\mathrm{Ce}_{6} \mathrm{Ni}_{1.67} \mathrm{Si}_{3}$ and $\mathrm{Ce}_{5} \mathrm{Ni}_{1.85} \mathrm{Si}_{3}$. The investigation of these ternary silicides based on nickel and $\mathrm{Ce}_{6} \mathrm{Co}_{1.67} \mathrm{Si}_{3}$ by $\mathrm{X}$-ray diffraction on single crystal reveals an ordered distribution between Ni- (or Co-) and Si-atoms. The nickel or cobalt positions in the chains of face-shared octahedra of cerium are not fully occupied with a strong delocalisation of their electron density. The structural investigations of these compounds confirm that the "Ce $\mathrm{Ci}_{2} \mathrm{Si}_{3}$ " and "Ce $\mathrm{Ci}_{2} \mathrm{Si}_{3}$ " structural-type have to be rewritten $\mathrm{Ce}_{6} \mathrm{Ni}_{2-\mathrm{x}} \mathrm{Si}_{3}$ and $\mathrm{Ce}_{5} \mathrm{Ni}_{2-\mathrm{x}} \mathrm{Si}_{3}$. Magnetization and specific heat measurements evidence a magnetic ordering at 3.8(2) $\mathrm{K}$ for $\mathrm{Ce}_{6} \mathrm{Ni}_{1.67} \mathrm{Si}_{3}$ and an heavy fermion behaviour for $\mathrm{Ce}_{6} \mathrm{Co}_{1.67} \mathrm{Si}_{3}$.
\end{abstract}

Keywords: Crystal structure; disordered structures; Magnetic order; Heavy fermion 


\section{Introduction}

The family of ternary silicides $\mathrm{RE}_{6} \mathrm{Ni}_{2} \mathrm{Si}_{3}$ with $\mathrm{RE}=\mathrm{La}$, Ce, Pr and Nd was discovered by Bodak et al. [1]. Using X-ray diffraction films, these authors have determined the structure of the so-called "Ce${ }_{6} \mathrm{Ni}_{2} \mathrm{Si}_{3}$ " compound which crystallizes with the space group $P 6_{3} / m$. Its structure is characterized by infinite chains of face-shared $\left[\mathrm{Ce}_{6}\right]$ octahedra running along the $c$ axis and triangular columns of centred $\left[\mathrm{Ce}_{6}\right]$ trigonal prisms sharing faces. $\mathrm{Ni}$ atoms occupy the centres of the octahedra, whereas the centre of trigonal prisms is occupied in part by Si atoms alone and in part by a $\mathrm{Ni} / \mathrm{Si}(2 \mathrm{Ni} / 4 \mathrm{Si})$ mixture. Moreover, this structure leads to very short Ni-Ni distances (2.162 $\AA$ compared to the metallic radius $\mathrm{r}_{\mathrm{Ni}}=1.246 \AA$ ) between two $\left[\mathrm{Ce}_{6}\right]$ octahedra along the $c$ axis.

Recently, the ternary silicides $\mathrm{La}_{6} \mathrm{Ni}_{1.54} \mathrm{Si}_{3}$ and $\mathrm{Nd}_{6} \mathrm{Ni}_{1.66} \mathrm{Si}_{3}$ deriving from the $\mathrm{Ce}_{6} \mathrm{Ni}_{2} \mathrm{Si}_{3}-$ type structure were prepared [2, 3]. In these structural determinations, it was reported that NiSi sublattice forms an ordered distribution. Also, it was claimed that the nickel sites on the $6_{3}$ axes (in the $\left[\mathrm{La}_{6}\right.$ or $\left.\mathrm{Nd}_{6}\right]$ octahedra) are not fully occupied and shifted in two positions for steric reasons. This structural model leads to Ni-Ni distances (2.818 $\AA$ ) between two $\left[\mathrm{Nd}_{6}\right]$ octahedra in $\mathrm{Nd}_{6} \mathrm{Ni}_{1.66} \mathrm{Si}_{3}$, compatible with the metallic radius of nickel [3].

More recently, we have reported on the existence of the ternary silicide based on cobalt $\mathrm{Gd}_{6} \mathrm{Co}_{1.67} \mathrm{Si}_{3}$ that orders ferromagnetically at $294 \mathrm{~K}$ [4] and is isotypic to $\mathrm{La}_{6} \mathrm{Ni}_{1.54} \mathrm{Si}_{3}$ and $\mathrm{Nd}_{6} \mathrm{Ni}_{1.66} \mathrm{Si}_{3}$. Moreover, extended study leads to synthesize the new ternary compounds $\mathrm{Nd}_{6} \mathrm{Co}_{1.67} \mathrm{Si}_{3}$ and $\mathrm{Tb}_{6} \mathrm{Co}_{1.67} \mathrm{Si}_{3}$ [5]. All these results suggest that the composition "Ce${ }_{6} \mathrm{Ni}_{2} \mathrm{Si}_{3}$ " could not exist as single phase. In order to answer at this question, we have prepared and characterized by X-ray diffraction on single crystal, the alloys "Ce $\mathrm{Ni}_{2} \mathrm{Si}_{3}$ " and $\mathrm{Ce}_{6} \mathrm{M}_{1.67} \mathrm{Si}_{3}$ $(\mathrm{M}=\mathrm{Co}, \mathrm{Ni})$. We present here the crystallographic and magnetic properties of $\mathrm{Ce}_{6} \mathrm{M}_{1.67} \mathrm{Si}_{3}$ and $\mathrm{Ce}_{5} \mathrm{Ni}_{1.85} \mathrm{Si}_{3}$, which is obtained by annealing of "Ce${ }_{6} \mathrm{Ni}_{2} \mathrm{Si}_{3}$ " composition at $1073 \mathrm{~K}$.

\section{Experimental details}

\subsection{Synthesis}

The polycrystalline $\mathrm{Ce}_{6} \mathrm{M}_{1.67} \mathrm{Si}_{3}(\mathrm{M}=\mathrm{Co}, \mathrm{Ni})$ and $" \mathrm{Ce}_{6} \mathrm{Ni}_{2} \mathrm{Si}_{3}$ " samples were synthesized by arc-melting a stoichiometric mixture of pure elements (purity above 99.9\%) in a high purity argon atmosphere. Then, the samples were turned over and remelted several times to ensure homogeneity. The weight loss during the arc-melting process was less than $0.5 w t \%$. Annealing was done for one month at $1073 \mathrm{~K}$ by enclosing the samples in evacuated quartz tubes. No attack of the quartz tubes by the samples and vice versa was observed. The 
stoichiometry deduced from the X-ray diffraction study of the single-crystal of the phase $\mathrm{Ce}_{5} \mathrm{Ni}_{2-\mathrm{x}} \mathrm{Si}_{3}$ found in the annealed alloy of "Ce${ }_{6} \mathrm{Ni}_{2} \mathrm{Si}_{3} "$ is $\mathrm{Ce}_{5} \mathrm{Ni}_{1.85} \mathrm{Si}_{3}$ (see below). A polycrystalline sample of this last ternary silicide has been prepared for magnetic measurements with the same procedure as the one used for $\mathrm{Ce}_{6} \mathrm{Ni}_{1.67} \mathrm{Si}_{3}$.

The as-cast and annealed samples of $" \mathrm{Ce}_{6} \mathrm{Ni}_{2} \mathrm{Si}_{3}$ " and $\mathrm{Ce}_{6} \mathrm{Ni}_{1.67} \mathrm{Si}_{3}$ were checked by microprobe analysis using a Cameca SX-100 instrument. The analysis was performed on the basis of intensity measurements of Ce $L \alpha_{1}$, Ni $K \alpha_{1}$ and Si $K \alpha_{1}$ X-ray emission lines, which were compared with those obtained for the equiatomic ternary silicide CeNiSi used as reference compound.

X-ray powder diffraction with the use of a Philips 1050-diffractometer ( $\mathrm{Cu} \mathrm{K \alpha}$ radiation) was applied, before and after annealing, for the characterization of the structural type and the phase identification of the samples.

\subsection{X-ray diffraction on single crystal}

Suitable single-crystals of $\mathrm{Ce}_{6} \mathrm{Ni}_{1.67} \mathrm{Si}_{3}, \mathrm{Ce}_{6} \mathrm{Co}_{1.67} \mathrm{Si}_{3}$ and $\mathrm{Ce}_{5} \mathrm{Ni}_{1.85} \mathrm{Si}_{3}$ were selected by optical microscopy. Reflection data were collected on an Enraf-Nonius Kappa CCD areadetector diffractometer at room temperature using Mo $K \alpha$ radiation. The single-crystals of $\mathrm{Ce}_{5} \mathrm{Ni}_{1.85} \mathrm{Si}_{3}$ were found in the annealed alloy of "Ce ${ }_{6} \mathrm{Ni}_{2} \mathrm{Si}_{3}$ ". Many crystals of $\mathrm{Ce}_{6} \mathrm{Co}_{1.67} \mathrm{Si}_{3}$ have been tested because of their poor quality, the best one being kept for the final data collection. A Gaussian-type absorption correction was applied, the shape of the crystals being determined with the video microscope of the diffractometer. Data processing and all refinements were performed with the JANA2000 program package [6]. Details of data collections and structure refinements are listed in table 1.

\subsection{Magnetization and specific heat measurements}

Magnetization measurements were performed using a Superconducting QUantum Interference Device (SQUID) magnetometer in the temperature range 1.8-370 K and applied fields up to 5 T. Heat capacity measurements were realized by a relaxation method with a Quantum Design PPMS system and using a two tau model analysis.

\section{Results and discussion}




\subsection{Existence of phases}

The analysis of "Ce${ }_{6} \mathrm{Ni}_{2} \mathrm{Si}_{3}$ " as-cast sample by $\mathrm{X}$-ray powder diffraction reveals the presence of two phases (Fig. 1) : (i) one main phase which crystallizes in the hexagonal unit with cell parameters $a=12.06(2) \AA$ and $c=4.31(1) \AA$ and (ii) the binary compound $\mathrm{Ce}_{7} \mathrm{Ni}_{3}$ [7]. This result is confirmed by microprobe analysis of the sample. These phases are clearly distinguished on the characteristic microstructure (back-scattered image) presented in figure 2 : (i) one showing white grey ranges, which corresponds to $\mathrm{Ce}_{7} \mathrm{Ni}_{3}$ and (ii) the second (grey) having Ce 56.1(4) \%, Ni 15.1(3) \% and Si 28.8(4) \% as experimental atomic percentages. This last chemical composition is typical to the $\mathrm{Ce}_{6} \mathrm{Ni}_{1.61(3)} \mathrm{Si}_{3.08(4)}$ ternary silicide. In other words, the study indicates that " $\mathrm{Ce}_{6} \mathrm{Ni}_{2} \mathrm{Si}_{3}$ " (Ce $54.5 \%$, Ni $18.2 \%$ and Si $27.3 \%$ ) cannot be obtained as single phase by melting followed by quenching.

Moreover, the X-ray powder pattern of " $\mathrm{Ce}_{6} \mathrm{Ni}_{2} \mathrm{Si}_{3}$ " annealed sample (Fig. 1) shows the occurrence of another phase; the main peaks attributed to this phase can be indexed with the hexagonal unit cell parameters $a=16.01(2) \AA$ and $c=4.26(1) \AA$. The microprobe analysis of this last phase (Ce 50.8(4) \%, Ni 18.2(3) \% and Si 31.0(4) \%) suggests the presence of $\mathrm{Ce}_{5} \mathrm{Ni}_{1.79(3)} \mathrm{Si}_{3.05(4)}$ in the annealed sample. It should be noted that two isotype compounds $\mathrm{La}_{5} \mathrm{Ni}_{1.75} \mathrm{Si}_{3}$ and $\mathrm{Pr}_{5} \mathrm{Ni}_{1.9} \mathrm{Si}_{3}$ were prepared recently [2, 8]. In conclusion, the ternary silicide " $\mathrm{Ce}_{6} \mathrm{Ni}_{2} \mathrm{Si}_{3}$ " does not exist but the characterization of this alloy (obtained after melting and quenching or after annealing at $1073 \mathrm{~K}$ ) indicates the existence of two ternary compounds $\mathrm{Ce}_{6} \mathrm{Ni}_{1.61(3)} \mathrm{Si}_{3.08(4)}$ and $\mathrm{Ce}_{5} \mathrm{Ni}_{1.79(3)} \mathrm{Si}_{3.05(4)}$.

On the contrary, X-ray powder diffraction analysis performed on as-cast or annealed $\mathrm{Ce}_{6} \mathrm{Ni}_{1.67} \mathrm{Si}_{3}$ sample (Fig. 3) reveals no phase coexistence; these patterns are indexed with the hexagonal unit cell parameters $a=12.06(2) \AA$ and $c=4.31(1) \AA$. After melting, some traces of $\mathrm{Ce}_{5} \mathrm{Si}_{3}$ binary silicide are detected [9] but disappear after annealing. These results show that $\mathrm{Ce}_{6} \mathrm{Ni}_{1.67} \mathrm{Si}_{3}$, detected by X-ray powder diffraction and microprobe analysis in the "Ce ${ }_{6} \mathrm{Ni}_{2} \mathrm{Si}_{3}$ " as-cast alloy, is a new member of the family $\mathrm{RE}_{6} \mathrm{Ni}_{1.67-\mathrm{x}} \mathrm{Si}_{3}$ reported previously for $\mathrm{RE}=\mathrm{La}$ and $\mathrm{Nd}[2,3]$. The synthesis of the hexagonal phase $\mathrm{Ce}_{5} \mathrm{Ni}_{1.85} \mathrm{Si}_{3}$ with the stoichiometry deduced from the single-crystal XRD study (see below) led to a pure sample with cell parameters $\mathrm{a}=16.011(6)$ and $\mathrm{c}=4.263(5) \AA$. This stoichiometry is very close to the one deduced from the microprobe analysis.

Similar investigation performed on $\mathrm{Ce}_{6} \mathrm{Co}_{1.67} \mathrm{Si}_{3}$ sample reveals the existence of this new ternary silicide crystallizing as $\mathrm{Ce}_{6} \mathrm{Ni}_{1.67} \mathrm{Si}_{3}$ in the hexagonal unit cell $(a=12.04(2) \AA$ and $c=$ 4.27(1) $\AA$ ). The compounds $\mathrm{RE}_{6} \mathrm{Co}_{1.67} \mathrm{Si}_{3}$ prepared recently by us for $\mathrm{RE}=\mathrm{Gd}$ [4], can be obtained for instance with $\mathrm{RE}=\mathrm{Nd}$ and $\mathrm{Tb}$ [5]. 


\subsection{Crystal structure}

\section{2.a. $\mathrm{Ce}_{6} \mathrm{Ni}_{1.67} \mathrm{Si}_{3}$}

The space group $P 6_{3} / m$, previously used for the refinement of $\mathrm{Ce}_{6} \mathrm{Ni}_{2} \mathrm{Si}_{3}$ and the homologous compounds $\mathrm{La}_{6} \mathrm{Ni}_{1.54} \mathrm{Si}_{3}$ and $\mathrm{Nd}_{6} \mathrm{Ni}_{1.66} \mathrm{Si}_{3}$ [1-3], was found to be compatible with the observed extinction rules for $\mathrm{Ce}_{6} \mathrm{Ni}_{1.67} \mathrm{Si}_{3}$. The starting atomic coordinates were determined with direct method. The Ce1 and Ce2 positions correspond to the $6 h$ Wyckoff positions (Table 2), silicon and nickel (Ni2) atoms are ordered over the $6 h$ and $2 d$ sites. When the $\mathrm{Ce} 1, \mathrm{Ce} 2, \mathrm{Ni2}$, and $\mathrm{Si}$ atoms were introduced, the difference-Fourier maps analysis showed clearly significant residues in $\left(\begin{array}{lll}0 & 0 & 1 / 4\end{array}\right)$. Then, the Ni3 atom has been placed at this last position and its occupancy factor refined but small residues in the difference-Fourier maps were found around the site $\left(\begin{array}{lll}0 & 0 & 0\end{array}\right)$. The Ni1 position was placed with coordinates $\left(\begin{array}{lll}0 & 0 & 0\end{array}\right)$ and the occupancy factor refined. When anisotropic Atomic Displacement Parameters (ADP) were introduced, non-definite positive ADP matrix was observed for Ni1 position with very high value of $\mathrm{U}^{33}$. To avoid this problem the Ni1 position has been shifted away from the $\left(\begin{array}{ll}0 & 0\end{array}\right.$ 0) (Table 2). The use of anisotropic ADP for all positions and refined occupancy factors of Ni1 and Ni3 positions led to reliability factors of $\mathrm{R} / \mathrm{Rw}(\mathrm{all})=0.039 / 0.076$. This structural model is very close to the ones proposed by Prots et al. for $\mathrm{La}_{6} \mathrm{Ni}_{1.54} \mathrm{Si}_{3}$ and $\mathrm{Nd}_{6} \mathrm{Ni}_{1.66} \mathrm{Si}_{3}[2$, 3]. Occupancy factors of all positions have been released to be sure that the distribution between $\mathrm{Ni}$ and $\mathrm{Si}$ is correct and then all occupancy factors have been fixed to their ideal value, except for Ni1 and Ni3 atoms. As previously pointed by Prots et al. [2, 3] the description of the delocalisation of the electron density along the chain in $(00 \mathrm{z})$ is a critical point in this structural type. To better understand this problem the next step of our refinement need to be detailed.

The Fourier map (Fig. 4) calculated after the first refinement (vide supra) shows the strong delocalisation of the electron density along the $\left(\begin{array}{lll}0 & 0 \mathrm{z}\end{array}\right)$ direction. Moreover a significant delocalisation of the Ni3 density in the $a b$ plane (Fig. 4) is observed. This delocalisation is not enough strong to be described with splitting positions then a development, up to third order, of ADP for Ni3 position was introduced. This last model leads to lower difference-Fourier residues. Two contour maps of the joint probability density function (j.p.d.f.) of the Ni1 and Ni3 positions have been drawn in figure 5. These maps are in good agreement with the Fourier maps (Fig. 4) except the fact that no maximum corresponding to the Ni1 position is observed in the Fourier map. The introduction of the Ni1 position is necessary to describe the 
delocalisation of the electron density along the $(00 \mathrm{z})$ axis. The main position for nickel atoms in the chain is $\mathrm{Ni3}$ (Table 2). The delocalisation of the Ni3 position in the $a b$ plane induces shorter distances with the neighbourhood Ce1 atoms. This steric strain explains the significant deformation of the thermal ellipsoid of the Ce1 positions in the $a b$ plane (Table 3). The motion or vibration of cerium atoms in the $a b$ plane is possible because of empty space in the structure (Fig. 6).

The formula deduced from the single-crystal data refinement, $\mathrm{Ce}_{6} \mathrm{Ni}_{1.68(8)} \mathrm{Si}_{3}$ (Table 2), is very close to the one deduced from the microprobe analysis, $\mathrm{Ce}_{6} \mathrm{Ni}_{1.61(3)} \mathrm{Si}_{3.08(4) \text {. This }}$ composition is significantly different from the ideal one, $\mathrm{Ce}_{6} \mathrm{Ni}_{2} \mathrm{Si}_{3}$, proposed by Bodak et al. [1]. This latter composition is not compatible with the steric strains in this structural type. Indeed as firstly proposed by Lemaire et al. [10] for $\mathrm{RE}_{4} \mathrm{Co}_{3.07}\left(\right.$ or $\mathrm{RE}_{6} \mathrm{Co}_{4.61}$ ) series $(\mathrm{RE}=$ rare earth), the steric strains between positions of Co in the chain $\left(\begin{array}{lll}0 & 0 & z\end{array}\right)$ imply a non stoichiometry of these phases, empty space are needed to manage realistic Co-Co distances. The overall formula of the series $\mathrm{RE}_{6} \mathrm{Co}_{4.61}$ can be expressed as $\mathrm{RE}_{6} \mathrm{Co}_{1.61} \mathrm{Co}_{3}$, to emphasize the structural similarity with $\mathrm{Ce}_{6} \mathrm{Ni}_{1.67} \mathrm{Si}_{3}$. These authors proposed the limit composition $\mathrm{RE}_{6} \mathrm{Co}_{1.67} \mathrm{Co}_{3}$ for this series and they have observed such limit when they have attempted to prepare $\mathrm{Ho}_{6} \mathrm{Co}_{1.75} \mathrm{Co}_{3}$. In their model, they have observed only one site for Co in the chain $(0$ $0 \mathrm{z}$ ), this site corresponding to the Ni1 site of our model (same notation for ref. [2, 3]). If two third of this position are occupied by Co atoms, a shift away from the ideal position $\left(\begin{array}{lll}0 & 0 & 0\end{array}\right)$ allows realistic distances between Co atoms. In $\mathrm{Ce}_{6} \mathrm{Ni}_{1.67} \mathrm{Si}_{3}$, the same discussion about an ideal distribution of $\mathrm{Ni}$ atoms can be done by considering only the $\mathrm{Ni} 3$ position. This position is strongly delocalised along the $z$ axis to manage realistic Ni-Ni distances. One can observe that our chemical composition deduced from microprobe analysis and structural refinement and the compositions reported from structural refinements by Prots et al. [2, 3] are in good agreement with the limit composition proposed by Lemaire et al. [10]. Prots et al. have proposed a relationship between the occupancy ratio of $\mathrm{Ni} 1$ and $\mathrm{Ni3}$ and the overall composition. They assumed that the maximum number of $\mathrm{Ni}$ in the chain $\left(\begin{array}{lll}0 & 0 \mathrm{z}\end{array}\right)$ is directly connected to the ratio between occupancy of $\mathrm{Ni1}$ and Ni3 positions [2]. This would imply that for all ternary compounds with composition $\mathrm{RE}_{6} \mathrm{Ni}_{1.67} \mathrm{Si}_{3}$ the same ratio should be observed. This is not the case in the sequence $\mathrm{La}_{6} \mathrm{Ni}_{1.54} \mathrm{Si}_{3} \rightarrow \mathrm{Ce}_{6} \mathrm{Ni}_{1.67} \mathrm{Si}_{3} \rightarrow \mathrm{Nd}_{6} \mathrm{Ni}_{1.66} \mathrm{Si}_{3}$. The $4 e$ site $(0$ $0 \mathrm{z}$ ) of the Ni1 position is more and more occupied; its occupancy ratio is $9.4 \%, 13 \%$ and 20.3 \% respectively for ternary compounds based on La, Ce and Nd. On the contrary, the

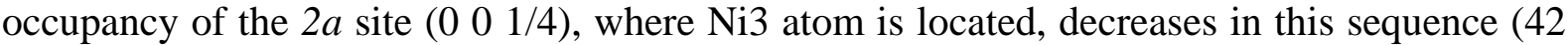
$\%$ in $\mathrm{Ce}_{6} \mathrm{Ni}_{1.67} \mathrm{Si}_{3}$ and $25 \%$ in $\mathrm{Nd}_{6} \mathrm{Ni}_{1.66} \mathrm{Si}_{3}$; it is difficult to consider this occupancy (35.5\%) 
for $\mathrm{La}_{6} \mathrm{Ni}_{1.54} \mathrm{Si}_{3}$ which exhibits a smaller composition in $\mathrm{Ni}$ ). The competition between the filling of the $4 e$ and $2 a$ sites by $\mathrm{Ni}$ atom can be explained on the basis of steric considerations. The interatomic distances RE1-Ni3 (2.830 $\AA$ in $\left.\mathrm{Ce}_{6} \mathrm{Ni}_{1.67} \mathrm{Si}_{3}\right)$ are really short and smaller than the RE1-Ni1 distance (2.903 $\AA$ in $\mathrm{Ce}_{6} \mathrm{Ni}_{1.67} \mathrm{Si}_{3}$ ) (Table 4); when the steric strain increases with decreasing metallic radius of the rare earth $(\mathrm{La} \rightarrow \mathrm{Ce} \rightarrow \mathrm{Nd}$ ), the $4 e$ site (Ni1 atom) which favours the greater RE1-Ni1 distances is more and more occupied. In this view and in order to keep the stoichiometry of the ternary silicide, the occupancy of the $2 a$ site ( $\mathrm{Ni} 3$ atom) decreases. In other words, the $\mathrm{Ni}$ distribution in the crystal structure of the $\mathrm{RE}_{6} \mathrm{Ni}_{\cong 1.67} \mathrm{Si}_{3}$ ternary silicides is connected to the nature of the rare earth element. This explanation is in complete agreement with the structure of $\mathrm{Ho}_{6} \mathrm{Co}_{1.61} \mathrm{Co}_{3}$. Indeed, in this binary compound the rare-earth element is small and all the Co atoms located in the chain $(0 \mathrm{r})$ are found in the Ni1 position.

The unit cell parameters reported here for $\mathrm{Ce}_{6} \mathrm{Ni}_{1.67} \mathrm{Si}_{3}$ (Table 1) are smaller than those given for the hypothetic ternary silicide " $\mathrm{Ce}_{6} \mathrm{Ni}_{2} \mathrm{Si}_{3}{ }^{\prime}$ (a $=12.112 \AA$ and $\mathrm{c}=4.323 \AA$ ) [1]. Moreover, these two structures differ also from the Ni-Si sublattice; for $\mathrm{Ce}_{6} \mathrm{Ni}_{1.67} \mathrm{Si}_{3}$ a perfect distribution between $\mathrm{Ni}$ and $\mathrm{Si}$ is evidenced (Table 2) whereas for instance the site $6 \mathrm{~h}$ is statistically occupied by $\mathrm{Ni}$ and $\mathrm{Si}$ in " $\mathrm{Ce}_{6} \mathrm{Ni}_{2} \mathrm{Si}_{3}$ ". On the contrary, the crystal structure of $\mathrm{Ce}_{6} \mathrm{Ni}_{1.67} \mathrm{Si}_{3}$ can be considered as isotypic with those found for $\mathrm{La}_{6} \mathrm{Ni}_{1.54} \mathrm{Si}_{3}$ and $\mathrm{Nd}_{6} \mathrm{Ni}_{1.66} \mathrm{Si}_{3}$ $[2,3]$. The unit cell parameters of $\mathrm{Ce}_{6} \mathrm{Ni}_{1.67} \mathrm{Si}_{3}$ are intermediate between those reported for $\mathrm{La}_{6} \mathrm{Ni}_{1.54} \mathrm{Si}_{3}$ and $\mathrm{Nd}_{6} \mathrm{Ni}_{1.66} \mathrm{Si}_{3}$. This last observation suggests that cerium presents a trivalent state in the ternary silicide.

A projection of the structure along the $c$ axis is displayed in figure 6. This structure consists of two different types of chains of face-sharing trigonal prisms of Ce atoms filled by $\mathrm{Si}$ or $\mathrm{Ni}$ atoms. The $\mathrm{NiCe}_{3}$ chains filled by $\mathrm{Ni} 2$ atoms are surrounding by three $\mathrm{SiCe}_{3}$ chains, these chains being connected together by sharing faces. These four trigonal prisms chains form triangles in the $a b$ plane (Fig. 6). Between six triangles a chain of face-sharing octahedra of Ce is partially filled by $\mathrm{Ni}$ atoms (Ni1 and Ni3 positions).

$\mathrm{Ni} 2$ atoms are located in trigonal prisms $\left[\mathrm{Ce}_{6}\right]$ with Ni2-Ce distances of $3.020 \AA$. The distance between Ni2 atoms and neighbourhood Si atoms is equal to $2.440 \AA$. The Ni2-Ce distances are in good agreement with the sum of metallic radii $\left(\mathrm{r}_{\mathrm{Ni}}=1.246 \AA, \mathrm{r}_{\mathrm{Ce}}=1.825 \AA\right.$ and $r_{S i}=1.319 \AA$ ), whereas the Ni2-Si distance is a little bit short. The average Si-Ce distance in the $\mathrm{SiCe}_{3}$ chain of trigonal prism is equal to $3.126 \AA$. The trigonal prism of Ce filled by $\mathrm{Si}$ is bi-capped by two Ce atoms with Si-Ce distances of 3.160 and $3.297 \AA$. The Ni1 position is shifted away from the centre of the octahedra of Ce with a long and a short Ni1-Ce distance, 
3.21 and $2.903 \AA$ respectively. The Ni3 position is located in the shared faces of the column of Ce octahedra. This induces very short distance, $2.830 \AA$, between Ni3 and Ce1 atoms in the $a b$ plane. Ce atoms in the two opposite faces of the octahedra form an elongated trigonal prism with long Ni3-Ce1 distances of $3.555 \AA$. The coordination polyhedra of Ni3 can be described as a tri-capped elongated trigonal prism of Ce atoms.

The coordination polyedra of Ce1 and Ce2 atoms are quite complicated. Only Ce1 position is involved by the disorder in the chain of $\mathrm{Ni}(0 \mathrm{Oz})$. Ce1 is surrounded by $3 \mathrm{Si}, 10 \mathrm{Ce}$ atoms and by $2 \mathrm{Ni1}$ and $2 \mathrm{Ni3}$ positions (Table 4). These latter positions are not fully occupied, then a small statistical disorder around Ce1 position is expected. As previously discussed very short distance between Ce1 and Ni3 is observed. Ce2 is surrounded by $2 \mathrm{Ni}, 5 \mathrm{Si}$ and $10 \mathrm{Ce}$ atoms. All distances between $\mathrm{Ce} 2$ and neighbourhood atoms are in good agreement with the sum of metallic radii.

\section{2.b. $\mathrm{Ce}_{6} \mathrm{Co}_{1.67} \mathrm{Si}_{3}$}

The atomic coordinates determined here for $\mathrm{Ce}_{6} \mathrm{Ni}_{1.67} \mathrm{Si}_{3}$ have been used as starting point for the refinement of the crystal structure of $\mathrm{Ce}_{6} \mathrm{Co}_{1.67} \mathrm{Si}_{3}$ (space group $P 6_{3} / m$ ), Ni atoms being replaced by Co atoms. The ordering between Si and Co atoms has been confirmed through occupancy factor refinement. When Co1 and Co3 positions have been introduced to describe the electron density in the chain located at $\left(\begin{array}{lll}0 & 0 \mathrm{z}\end{array}\right)$, significant residues in the differenceFourier map have been observed. The main residues were located in the $a b$ plane with $\mathrm{z}=1 / 4$ around Co3 position (Fig. 7(left)). An extra cobalt position (Co4) has been introduced to explain these maxima in the difference-Fourier analysis (Table 2). The strong delocalisation observed in $\mathrm{Ce}_{6} \mathrm{Ni}_{1.67} \mathrm{Si}_{3}$ is so strong in $\mathrm{Ce}_{6} \mathrm{Co}_{1.67} \mathrm{Si}_{3}$ that a new position appears in the electron density around the Co3 position. All the refined Co positions are clearly observed on the Fourier map (Fig. 7(right)). One can notice that the electron density is less spread over the $(00 \mathrm{z})$ axis and is more localised around the Co positions.

The structure of $\mathrm{Ce}_{6} \mathrm{Co}_{1.67} \mathrm{Si}_{3}$ is close to that of $\mathrm{Ce}_{6} \mathrm{Ni}_{1.67} \mathrm{Si}_{3}$ with two main differences concerning the electron density along the $(00 \mathrm{z})$ axis. The first difference is the existence of a new Co4 position and the second one is the more important localisation of the electron density around the cobalt positions. The distance between Co4 and Ce1 is too short (2.08 $\AA$ ) and as previously discussed to manage realistic Co-Ce distances a displacement of Ce1 is expected. This displacement is reflected in the high values of $U^{11}$ and $U^{22}$ of Ce1 ADP's matrix (Table 3). The delocalisation is stronger with Co atoms then the $\mathrm{U}^{\mathrm{ij}}$ components for Ce1 in the $a b$ plane are higher to the ones observed for $\mathrm{Ce}_{6} \mathrm{Ni}_{1.67} \mathrm{Si}_{3}$. 
It is interesting to note that in the sequence $\mathrm{Ce}_{6} \mathrm{Ni}_{1.67} \mathrm{Si}_{3} \rightarrow \mathrm{Ce}_{6} \mathrm{Co}_{1.67} \mathrm{Si}_{3}$, the $a$ parameter decreases weakly (-0.1\%) whereas the $c$ parameter decreases more strongly (-0.9\%) (Table 1). Similar remark was made for the sequence $\mathrm{Ce}_{2} \mathrm{NiSi}_{3} \rightarrow \mathrm{Ce}_{2} \mathrm{CoSi}_{3}$; the crystal structure of these ternary silicides is described also by the stacking along the $c$ axis of [ $\mathrm{Ce}_{6}$ ] trigonal prism where Ni- or Co- and Si-atoms are located [11-13]. In other words, in these two families of ternary silicides, the $\left[\mathrm{Ce}_{6}\right]$ trigonal prisms containing Co atom are much compressed than those surrounding $\mathrm{Ni}$ atom; this is connected to the higher decrease of the $c$ parameter.

\section{2.c. $\mathrm{Ce}_{5} \mathrm{Ni}_{1.85} \mathrm{Si}_{3}$}

The extinction conditions observed for $\mathrm{Ce}_{5} \mathrm{Ni}_{1.85} \mathrm{Si}_{3}$ agree with the $P 6_{3} / m$ space group already used for the refinement of the homologous compounds $\mathrm{La}_{5} \mathrm{Ni}_{1.75} \mathrm{Si}_{3}$ and $\mathrm{Pr}_{5} \mathrm{Ni}_{1.9} \mathrm{Si}_{3}[2$, 8]. The starting atomic positions were those reported for $\mathrm{La}_{5} \mathrm{Ni}_{1.75} \mathrm{Si}_{3}$. The same ordered distribution between $\mathrm{Ni}$ and $\mathrm{Si}$ atoms has been observed on the $6 h$ sites (Table 2). The disordered positions of $\mathrm{Ni}$ along the chain $(0 \mathrm{l} \mathrm{z})$ are not exactly identical. The Ni3 position is still in $\left(\begin{array}{lll}0 & 0 & 1 / 4\end{array}\right)$ but Ni2 position is now on the $2 b$ site $\left(\begin{array}{lll}0 & 0 & 0\end{array}\right)$. The electron density along this chain is still strongly delocalised and this is reflected by the very high value of $U^{33}$ of the ADP matrix for Ni2 and Ni3 positions (Table 2), $0.117 \AA^{2}$ (the U matrixes were constraints to be the same because of high correlations).

As previously observed for $\mathrm{Ce}_{6} \mathrm{Ni}_{1.67} \mathrm{Si}_{3}$, the electron density along the $\left(\begin{array}{lll}0 & 0 \mathrm{z}\end{array}\right)$ axe is strongly delocalised and a small delocalisation of the Ni3 position in the $(a, b)$ plane has been also observed. The strong correlations in the refinement between ADP matrices and occupancy factors did not allow us to use a non-harmonic development of the ADP tensors to describe this last delocalisation. Two maxima are clearly observed in the Fourier map (calculated at the end of the refinement) displayed in figure 8(left) and correspond to the $\mathrm{Ni2}$ and Ni3 positions. These maxima are also observed in the difference-Fourier map when the structure is refined without $\mathrm{Ni}$ atoms along the $(0 \mathrm{O} \mathrm{z})$ axis (Fig. 8(middle)). The jpdf map calculated at the end of the refinement for the $\mathrm{Ni} 2$ and $\mathrm{Ni} 3$ positions confirms that our model is in very good agreement with this observation. A refinement with $\mathrm{Ni} 2$ in position $(0,0, \mathrm{z})$ (with $\mathrm{z}=0.078(6)$ ) led to similar reliability factors and electron residues but with different jpdf maps for $\mathrm{Ni}$ atoms along the $(0 \mathrm{z})$ axe (Fig. 8(right)); no maximum in the jpdf map is observed in the $(0,0,0)$ position. This induces that with the model used for $\mathrm{La}_{5} \mathrm{Ni}_{1.75} \mathrm{Si}_{3}$ and $\mathrm{Pr}_{5} \mathrm{Ni}_{1.9} \mathrm{Si}_{3}$ by previous workers, the calculated distances with $\mathrm{Ni} 2$ position in $\left(\begin{array}{lll}0 & 0 \mathrm{z}\end{array}\right)$ would have no real signification. As our and their structural models are different, it is difficult to compare the occupancy factors refined for the Ni2 and Ni3 positions. In $\mathrm{Ce}_{5} \mathrm{Ni}_{1.85} \mathrm{Si}_{3}$ more $\mathrm{Ni}$ 
atoms are located on $\mathrm{Ni} 3$ than on $\mathrm{Ni} 2$ position. If this is also the case for $\mathrm{La}_{5} \mathrm{Ni}_{1.75} \mathrm{Si}_{3}$, the reverse situation is observed for $\operatorname{Pr}_{5} \mathrm{Ni}_{1.9} \mathrm{Si}_{3}$.

If one considers an ideal distribution of $\mathrm{Ni}$ atoms only on $\mathrm{Ni3}$ positions a similar model to the one proposed by Lemaire et al. for $\mathrm{Ho}_{6} \mathrm{Co}_{1.61} \mathrm{Co}_{3}$ can be imagined: Two consecutive positions are filled by $\mathrm{Ni}$ atoms with a little shift away from the ideal position to increase the Ni3-Ni3 distance (2.1351 $\AA$ ) and these kind of pairs of atoms would be separated by one empty position. This simple model would lead to the ideal composition $\mathrm{Ce}_{5} \mathrm{Ni}_{1.833} \mathrm{Si}_{3}$ that is very close to the refined stoichiometry. Moreover the necessity to increase the Ni3-Ni3 distances would explain the strong deformation of the electron density around the Ni3 position.

A projection of the crystal structure of $\mathrm{Ce}_{5} \mathrm{Ni}_{1.85} \mathrm{Si}_{3}$ is displayed in figure 6 . This structure is the member $n=3$ of the series $\mathrm{RE}_{(\mathrm{n}+1)(\mathrm{n}+2)} \mathrm{Ni}_{n(n-1)+2} \mathrm{Si}_{n(n+1)}$ [2]. Nine chain of face-sharing trigonal prism of cerium $\left[\mathrm{Ce}_{6}\right]$ form a triangle. These chains filled by Ni1 and Si atoms are connected together through shared faces. The trigonal prisms surrounding Si1 and Si2 atoms are mono- and bi-capped by Ce atoms, respectively. Ni1-Ce average distance is equal to 3.062 $\AA$ and Si-Ce distances are ranging from 3.085 to $3.311 \AA$ (Table 4). All these distances are in good agreement with the sum of the metallic radii, 3.071 and $3.144 \AA$ for $\mathrm{r}_{\mathrm{Ni}}+\mathrm{r}_{\mathrm{Ce}}$ and $\mathrm{r}_{\mathrm{Si}}+\mathrm{r}_{\mathrm{Ce}}$, respectively. Between the triangles of chains of $\left[\mathrm{Ce}_{6}\right]$ trigonal prisms, a chain of face-shared octahedra of $\mathrm{Ce}$ is filled by $\mathrm{Ni} 2$ and $\mathrm{Ni} 3$ atoms. $\mathrm{Ni} 2$ atoms are exactly at the centre of the octahedra with Ni2-Ce1 distance of $3.0169 \AA$. These distances are relatively short and this would be correlated to the low occupancy of this $2 b$ site and the strong delocalisation of the $\mathrm{Ni}$ atoms in this chain. $\mathrm{Ni3}$ positions are on the face of the octahedra in a tri-capped elongated trigonal prism with six long Ni3-Ce1 distances (3.5384 $\AA$ ) and three short Ni3-Ce1 distance (2.8217 $\AA$ ). In this crystal structure, Ce1 atoms exhibit also high ADP in $a b$ plane to manage the steric strains (Table 3).

\subsection{Magnetic properties}

The temperature dependence of the reciprocal magnetic susceptibility $\chi_{\mathrm{m}}{ }^{-1}$ of $\mathrm{Ce}_{6} \mathrm{Ni}_{1.67} \mathrm{Si}_{3}$ and $\mathrm{Ce}_{6} \mathrm{Co}_{1.67} \mathrm{Si}_{3}$, measured with an applied field of $4 \mathrm{~T}$, is displayed in figure 9. Above 150 $K$, these $\chi_{\mathrm{m}}{ }^{-1}=\mathrm{f}(\mathrm{T})$ curves follow a Curie-Weiss law. The experimental value of the effective magnetic moment $\mu_{\text {eff. }}$ is $2.45 \mu_{\mathrm{B}} / \mathrm{Ce}$ for $\mathrm{Ce}_{6} \mathrm{Ni}_{1.67} \mathrm{Si}_{3}$ and $2.59 \mu_{\mathrm{B}} / \mathrm{Ce}$ for $\mathrm{Ce}_{6} \mathrm{Co}_{1.67} \mathrm{Si}_{3}$, which is close to the calculated one for a free $\mathrm{Ce}^{3+}$ ion $\left(2.54 \mu_{\mathrm{B}} / \mathrm{Ce}\right)$. At low temperature than $150 \mathrm{~K}$, the $\chi_{\mathrm{m}}{ }^{-1}=\mathrm{f}(\mathrm{T})$ curves deviate from a straight-line behaviour, presumably due to thermal 
depopulation of crystal-field levels. The paramagnetic Curie temperature $\theta_{\mathrm{p}}$ is found to be -36 $\mathrm{K}$ for $\mathrm{Ce}_{6} \mathrm{Ni}_{1.67} \mathrm{Si}_{3}$ and $-77 \mathrm{~K}$ for $\mathrm{Ce}_{6} \mathrm{Co}_{1.67} \mathrm{Si}_{3}$. Such a large negative value of the paramagnetic Curie temperature is often found in Kondo compounds. It is important to note that $\theta_{\mathrm{p}}$ is higher for $\mathrm{Ce}_{6} \mathrm{Ni}_{1.67} \mathrm{Si}_{3}$ than for $\mathrm{Ce}_{6} \mathrm{Co}_{1.67} \mathrm{Si}_{3}$. Similar increase of $\theta_{\mathrm{p}}$ was observed in the sequence $\mathrm{Ce}_{2} \mathrm{CoSi}_{3}\left(\theta_{\mathrm{p}}=-107 \mathrm{~K}\right) \rightarrow \mathrm{Ce}_{2} \mathrm{NiSi}_{3}\left(\theta_{\mathrm{p}}=-22 \mathrm{~K}\right)$ [13]; the structural properties of these last ternary compounds show, as mentioned above, many similarities with $\mathrm{Ce}_{6} \mathrm{Ni}_{1.67} \mathrm{Si}_{3}$ and $\mathrm{Ce}_{6} \mathrm{Co}_{1.67} \mathrm{Si}_{3}$.

No magnetic ordering can be detected above $1.8 \mathrm{~K}$ by magnetization measurements performed on $\mathrm{Ce}_{6} \mathrm{Co}_{1.67} \mathrm{Si}_{3}$ (Fig. 10(a)); its magnetization becomes monotonically decreasing function of the temperature without any indication of the ordering. On the contrary, different behaviour is observed for $\mathrm{Ce}_{6} \mathrm{Ni}_{1.67} \mathrm{Si}_{3}$ (Fig. 10(b)); its magnetization (i) is higher than that observed for $\mathrm{Ce}_{6} \mathrm{Co}_{1.67} \mathrm{Si}_{3}$ and (ii) tends to saturate below $\mathrm{T}_{\mathrm{t}}=3.8(2) \mathrm{K}$ (the temperature where the derivative curve $d\left(M / \mu_{0} H\right) / d T=f(T)$ exhibits a maximum). This preliminary study suggests the establishment of long-range magnetic correlations below $T_{t}=3.8(2) \mathrm{K}$ in $\mathrm{Ce}_{6} \mathrm{Ni}_{1.67} \mathrm{Si}_{3}$. More information obtained for instance by ac-magnetic susceptibility measurements or neutron powder diffraction are necessary in order to understand the nature of the magnetic ordering appearing below $\mathrm{T}_{\mathrm{t}}$ in this last ternary silicide.

These different magnetic behaviours between $\mathrm{Ce}_{6} \mathrm{Co}_{1.67} \mathrm{Si}_{3}$ and $\mathrm{Ce}_{6} \mathrm{Ni}_{1.67} \mathrm{Si}_{3}$ are clearly evidenced by specific heat measurements (Fig. 11). No anomaly can be distinguished from the $\mathrm{C}_{\mathrm{p}}=\mathrm{f}(\mathrm{T})$ curve concerning $\mathrm{Ce}_{6} \mathrm{Co}_{1.67} \mathrm{Si}_{3}$ in agreement with the absence of magnetic ordering above $1.8 \mathrm{~K}$ as observed by magnetization measurements. But below $6 \mathrm{~K}$, the curve $\mathrm{C}_{\mathrm{p}} / \mathrm{T}=$ $\mathrm{f}(\mathrm{T})$ (inset of Fig. 11) exhibits an upturn attaining a value of $389 \mathrm{~mJ} / \mathrm{Ce}-\mathrm{mol} \mathrm{K}^{2}$ at $1.9 \mathrm{~K}$ as if the compound is a heavy-fermion; alternatively, a possible magnetic ordering well below 1.9 $\mathrm{K}$ also can contribute to the low temperature enhancement of $\mathrm{C}_{\mathrm{p}} / \mathrm{T}$. It may be mentioned that between $10 \mathrm{~K}$ and $22 \mathrm{~K}$, we can obtain the electronic coefficient $\gamma_{\mathrm{LT}}$ by fitting the data to the formula $\mathrm{C}_{\mathrm{p}} / \mathrm{T}=\gamma_{\mathrm{LT}}+\beta_{\mathrm{LT}} \mathrm{T}^{2}$. The obtained values were $\gamma_{\mathrm{LT}}=162 \mathrm{~mJ} / \mathrm{Ce}-\mathrm{mol} \mathrm{K} \mathrm{K}^{2}$ and $\beta_{\mathrm{LT}}=3.47$ $10^{-4} \mathrm{~J} / \mathrm{Ce}-\mathrm{mol} \mathrm{K}^{4}$. Considering this value of $\gamma_{\mathrm{LT}}$ we could define this ternary silicide as a moderate heavy fermion system. Finally, we note that this $\gamma_{\mathrm{LT}}$-value is higher than that reported for the intermediate valence compounds $\mathrm{Ce}_{2} \mathrm{CoSi}_{3}\left(\gamma_{\mathrm{LT}}=59.7 \mathrm{~mJ} / \mathrm{Ce}-\mathrm{mol} \mathrm{K}^{2}\right)[13,15$, 16]. On the contrary, the curve $\mathrm{C}_{\mathrm{p}}=\mathrm{f}(\mathrm{T})$ for $\mathrm{Ce}_{6} \mathrm{Ni}_{1.67} \mathrm{Si}_{3}$ (Fig. 11) exhibits a peak at about 4.1(2) $\mathrm{K}$ and a peak value approaching $5.36 \mathrm{~J} / \mathrm{Ce}-\mathrm{mol} \mathrm{K}$. The temperature of the heat-capacity peak is practically the same as the temperature where the derivative curve of the magnetization $d\left(M / \mu_{0} H\right) / d T=f(T)$ exhibits a maximum (Fig. 10(b)) confirming the 
occurrence of magnetic ordering below $\mathrm{T}_{\mathrm{t}}$. Valuable information can be obtained from the entropy associated with the magnetic ordering of $\mathrm{Ce}_{6} \mathrm{Ni}_{1.67} \mathrm{Si}_{3}$, which is estimated from the magnetic contribution to the specific heat in the low-temperature range as $C_{p}$ mag $=C_{p}-(\gamma T$ $+\beta \mathrm{T}^{3}$ ) (between 10 and $22 \mathrm{~K}$, the fitting of $\mathrm{C}_{\mathrm{p}} / \mathrm{T}=\gamma+\beta \mathrm{T}^{2}$ yields to a electronic coefficient $\gamma=$ $144 \mathrm{~mJ} / \mathrm{Ce}-\mathrm{mol} \mathrm{K}{ }^{2}$ smaller than that determined for $\mathrm{Ce}_{6} \mathrm{Co}_{1.67} \mathrm{Si}_{3}$ and phonon constant $\beta=$ $2.2910^{-4} \mathrm{~J} / \mathrm{Ce}-\mathrm{mol} \mathrm{K}{ }^{4}$ ). At $\mathrm{T}_{\mathrm{t}}$, the magnetic entropy reaches $3.75 \mathrm{~J} / \mathrm{Ce}-\mathrm{mol} \mathrm{K}=0.65 \mathrm{RLn} 2$ which is smaller than RLn2 $=5.76 \mathrm{~J} / \mathrm{Ce}$-mol $\mathrm{K}$, the value of magnetic entropy expected for a doublet ground state of $\mathrm{Ce}^{3+}$. This reduction suggests the presence of a moderate Kondo effect in this ternary silicide $\mathrm{Ce}_{6} \mathrm{Ni}_{1.67} \mathrm{Si}_{3}$.

Above $150 \mathrm{~K}$, the curve $\chi_{\mathrm{m}}{ }^{-1}=\mathrm{f}(\mathrm{T})$ (not shown here) for $\mathrm{Ce}_{5} \mathrm{Ni}_{1.85} \mathrm{Si}_{3}$ follows a CurieWeiss law with $\mu_{\text {eff }}=2.51 \mu_{\mathrm{B}} / \mathrm{Ce}$ and $\theta_{\mathrm{p}}=-43 \mathrm{~K}$ as effective moment and paramagnetic Curie temperature. These values are comparable to those reported for the ternary silicide $\mathrm{Ce}_{5} \mathrm{Ni}_{2} \mathrm{Si}_{3}$ : $\mu_{\text {eff }}=2.42 \mu_{\mathrm{B}} / \mathrm{Ce}$ and $\theta_{\mathrm{p}}=-61.3 \mathrm{~K}$ [14]. Considering both the previous works devoted to $\mathrm{La}_{5} \mathrm{Ni}_{1.75} \mathrm{Si}_{3}$ [2] and $\mathrm{Pr}_{5} \mathrm{Ni}_{1.9} \mathrm{Si}_{3}$ [6] and the present study on $\mathrm{Ce}_{5} \mathrm{Ni}_{1.85} \mathrm{Si}_{3}$, we assume that the $\mathrm{Ce}_{5} \mathrm{Ni}_{2} \mathrm{Si}_{3}$ alloy corresponds to the single phase $\mathrm{Ce}_{5} \mathrm{Ni}_{1.85} \mathrm{Si}_{3}$. We note that the unit cell parameters determined here for this last ternary silicide (Table 1 ) are close to those reported for $\mathrm{Ce}_{5} \mathrm{Ni}_{2} \mathrm{Si}_{3}(\mathrm{a}=15.997(9) \AA$ and $\mathrm{c}=4.309(1) \AA)[11,14]$. At low temperature, the thermal dependence of the magnetization divided by applied field of $\mathrm{Ce}_{5} \mathrm{Ni}_{1.85} \mathrm{Si}_{3}$ shows a kink at $\mathrm{T}_{\mathrm{N}}=$ 4.8(2) K (Fig. 12). This behaviour suggests that this ternary silicide is antiferromagnetically ordered. This $\mathrm{T}_{\mathrm{N}}$-temperature is smaller than that reported previously for $\mathrm{Ce}_{5} \mathrm{Ni}_{2} \mathrm{Si}_{3}$ [14].

\section{Conclusion}

This study reveals that the ternary silicides $\mathrm{Ce}_{6} \mathrm{Ni}_{2} \mathrm{Si}_{3}$ and $\mathrm{Ce}_{5} \mathrm{Ni}_{2} \mathrm{Si}_{3}$ reported previously [1, $11,14]$ cannot be obtained as single phase. On the contrary, the microprobe analysis of these alloys allows the characterization of two new ternary compounds $\mathrm{Ce}_{6} \mathrm{Ni}_{1.67} \mathrm{Si}_{3}$ and $\mathrm{Ce}_{5} \mathrm{Ni}_{1.85} \mathrm{Si}_{3}$. Their investigation by $\mathrm{X}$-ray diffraction on single crystal shows a strong delocalisation of the electron density of the $\mathrm{Ni}$ in the infinite chain of face-shared octahedra of cerium. Similar crystallographic consideration was evidenced on the new compound based on cobalt $\mathrm{Ce}_{6} \mathrm{Co}_{1.67} \mathrm{Si}_{3}$. In this last compound, a higher delocalisation of the Co atoms in the [Ce1] triangle has been observed and leads to the existence of an extra position (Co4 position) very close to the cerium atoms (Ce1 position). This induces a strong deformation of the thermal ellipsoid of the Ce1 position. The preliminary study of their physical properties indicates that $\mathrm{Ce}_{6} \mathrm{Ni}_{1.67} \mathrm{Si}_{3}$ orders magnetically below $\mathrm{T}_{\mathrm{t}}=3.8(2) \mathrm{K}$ whereas $\mathrm{Ce}_{6} \mathrm{Co}_{1.67} \mathrm{Si}_{3}$ 
exhibits a heavy fermion behaviour. More information's obtained for instance by electrical resistivity measurement and neutron powder diffraction are necessary in order to establish a relationship between the atomic disorder existing in these phases and their physical properties.

\section{Acknowledgments}

We thank R. Decourt for the specific heat data collection. One of us (B. C.) wishes to thank European Science Foundation (ECOM-COST action P16) for financial support.

\section{References}

[1] O. I. Bodak, E. I. Gladyshevskii, O. I. Kharchenko, Kristallografiya 19, 80 (1974).

[2] Y. M. Prots and W. Jeitschko, Inorg. Chem. 37, 5431 (1998).

[3] Y. M. Prots and W. Jeitschko, J. Solid State Chem. 137, 302 (1998).

[4] E. Gaudin, F. Weill and B. Chevalier, Z. Naturforsch. 61b, 825 (2006).

[5] B. Chevalier, E. Gaudin, F. Weill, J. Alloys Comp. (to be published).

[6] V. Petricek, M. Dusek, The crystallographic computing system Jana2000, Institute of Physics, Praha, Czech Republic.

[7] G. L. Olcese, J. Less-Comm. Met., 33, 71 (1973).

[8] A. O. Pecharsky, Yu. Mozharivskyj, K. W. Dennis, K. A. Gschneidner Jr., R. W. McCallum, G. J. Miller and V. K. Pecharsky, Phys. Rev. B, 68, 134452 (2003).

[9] E. I. Gladyshevskii, P. I. Kripyakevich, Inorg. Mater., 1, 644 (1965).

[10] R. Lemaire, J. Schweizer and J. Ythos, Acta Cryst.B, 20, 710 (1969).

[11] E. I. Gladyshevskii, O. I. Bodak, Dopov. Akad. Nauk Ukrains’ koi RSR, 1965, 601 (1965).

[12] O. I. Bodak and E. I. Gladyshevskii, Izv. Akad. Nauk SSSR, Neorg. Mater., 6, 1186 (1970).

[13] R. A. Gordon, C. J. Waren, M. G. Alexander, F. J. DiSalvo, R. Pöttgen, J. Alloys Comp., 248, 24 (1997).

[14] B. K. Lee, D. H. Ryu, D. Y. Kim, J. B. Hong, M. H. Jung, H. Kitazawa, O. Suzuki, S. Kimura and Y. S. Kwon, Phys. Rev. B, 70, 224409 (2004).

[15] S. Majumdar, M. M. Kumar, R. Mallik, E. V. Sampathkumaran, Physica B, 281-282, 367 (2000).

[16] S. Majumdar, M. M. Kumar, R. Mallik, E. V. Sampathkumaran, Solid State Comm., 110, 509 (1999). 
Table 1. Crystal data and structure refinement for $\mathrm{Ce}_{6} \mathrm{Ni}_{1.67} \mathrm{Si}_{3}, \mathrm{Ce}_{5} \mathrm{Ni}_{1.85} \mathrm{Si}_{3}$ and $\mathrm{Ce}_{6} \mathrm{Co}_{1.67} \mathrm{Si}_{3}$

\begin{tabular}{|c|c|c|c|}
\hline composition & $\mathrm{Ce}_{6} \mathrm{Ni}_{1.68(8)} \mathrm{Si}_{3}$ & $\mathrm{Ce}_{5} \mathrm{Ni}_{1.851(9)} \mathrm{Si}_{3}$ & $\mathrm{Ce}_{6} \mathrm{Co}_{1.63(10)} \mathrm{Si}_{3}$ \\
\hline \multicolumn{4}{|l|}{ Crystal data } \\
\hline Chemical formula & $\mathrm{Ce}_{6} \mathrm{Ni}_{1.67} \mathrm{Si}_{3}$ & $\mathrm{Ce}_{5} \mathrm{Ni}_{1.85} \mathrm{Si}_{3}$ & $\mathrm{Ce}_{6} \mathrm{Co}_{1.67} \mathrm{Si}_{3}$ \\
\hline$M_{r}$ & 1023 & 892.4 & 1023.4 \\
\hline Cell setting, space group & \multicolumn{3}{|c|}{ Hexagonal, $\mathrm{P}_{3} / \mathrm{m}$} \\
\hline$a, c(\AA)$ & $12.0506(10), 4.3030(2)$ & 16.0014(15), 4.2701(2) & 12.039(2), 4.2624(6) \\
\hline$V\left(\AA^{3}\right)$ & $541.15(7)$ & $946.86(13)$ & $535.01(15)$ \\
\hline$Z$ & 2 & 4 & 2 \\
\hline$D_{x}\left(\mathrm{Mg} \mathrm{m}^{-3}\right)$ & 6.276 & 6.258 & 6.351 \\
\hline Radiation type & \multicolumn{3}{|c|}{ Mo $K \alpha$} \\
\hline No. of reflections for cell & 1522 & 393 & 393 \\
\hline$\theta$ range $\left(^{\circ}\right)$ & \multicolumn{3}{|c|}{$5-40$} \\
\hline$\mu\left(\mathrm{mm}^{-1}\right)$ & 27.78 & 27.38 & 27.75 \\
\hline Temperature (K) & \multicolumn{3}{|c|}{$293 \mathrm{~K}$} \\
\hline Crystal form, colour & \multicolumn{3}{|c|}{ Block, metallic light grey } \\
\hline Crystal size (mm) & $0.008 \times 0.018 \times 0.05$ & $0.08 \times 0.04 \times 0.018$ & $0.035 \times 0.018 \times 0.014$ \\
\hline \multicolumn{4}{|l|}{ Data collection } \\
\hline Diffractometer & \multicolumn{3}{|c|}{ Nonius KappaCCD } \\
\hline Data collection method & \multicolumn{3}{|c|}{$\phi$ and $\omega$ frames } \\
\hline Absorption correction & \multicolumn{3}{|c|}{ Gaussian } \\
\hline$T_{\min }$ & 0.201 & 0.238 & 0.453 \\
\hline$T_{\max }$ & 0.647 & 0.611 & 0.691 \\
\hline $\begin{array}{l}\text { No. of measured, independent } \\
\text { and observed reflections }\end{array}$ & 10285, 1220, 974 & 19367, 2139, 1675 & 7087, 1211, 536 \\
\hline Criterion for observed reflections & $I>2 \sigma(I)$ & $I>2 \sigma(I)$ & $I>3 \sigma(I)$ \\
\hline $\mathrm{R}_{\text {int }}(\mathrm{obs}), R_{\text {int }}($ all $)$ & $0.071,0.076$ & $0.079,0.085$ & $0.097,0.183$ \\
\hline$\theta_{\max }\left({ }^{\circ}\right)$ & & 40.0 & \\
\hline \multirow[t]{3}{*}{ Range of $h, k, l$} & $-21 \rightarrow h \rightarrow 19$ & $-28 \rightarrow h \rightarrow 28$ & $-21 \rightarrow h \rightarrow 20$ \\
\hline & $-21 \rightarrow k \rightarrow 21$ & $-28 \rightarrow k \rightarrow 28$ & $-21 \rightarrow k \rightarrow 21$ \\
\hline & $-6 \rightarrow l \rightarrow 7$ & $-7 \rightarrow l \rightarrow 7$ & $-7 \rightarrow l \rightarrow 3$ \\
\hline
\end{tabular}

\section{Refinement}

Refinement on

$R\left[F^{2}>2 \sigma\left(F^{2}\right)\right], w R\left(F^{2}\right), S$

$0.039,0.076,1.20$

$F^{2}$

No. of reflections

No. of parameters

1220 reflections

$0.035,0.072,1.11$

$0.049,0.114,1.12$

31

2139 reflections

1211 reflections

44

30

Weighting scheme

$(\Delta / \sigma)_{\max }$

Based on measured s.u.'s $w=1 /\left(\sigma^{2}(I)+0.0009 I^{2}\right)$

$\Delta \rho_{\max }, \Delta \rho_{\min }\left(\mathrm{e} \AA^{-3}\right)$

Extinction method

Extinction coefficient

Computer programs: (see ref. [6]). 
Table 2: Atomic coordinates and atomic displacement parameters for $\mathrm{Ce}_{6} \mathrm{Ni}_{1.67} \mathrm{Si}_{3}$, $\mathrm{Ce}_{6} \mathrm{Co}_{1.67} \mathrm{Si}_{3}, \mathrm{Ce}_{5} \mathrm{Ni}_{1.85} \mathrm{Si}_{3}$ (space group $\mathrm{P6}_{3} / \mathrm{m}$ ).

\begin{tabular}{|c|c|c|c|c|c|c|c|}
\hline & Atom & Site & $\mathrm{x}$ & $\mathrm{y}$ & $\mathrm{z}$ & $\mathrm{B}_{\mathrm{eq}}$ & Occ. \\
\hline \multirow[t]{6}{*}{$\mathrm{Ce}_{6} \mathrm{Ni}_{1.68(8)} \mathrm{Si}_{3}$} & Ce1 & $6 h$ & $0.23963(4)$ & $\begin{array}{l}0.22978(4) \\
\end{array}$ & $1 / 4$ & $1.527(12)$ & 1 \\
\hline & Ce2 & $6 h$ & $0.51905(3)$ & $0.13869(3)$ & $1 / 4$ & $0.936(9)$ & 1 \\
\hline & Ni1 & $4 e$ & 0 & 0 & $0.104(15)$ & $3.3(9)$ & $0.13(2)$ \\
\hline & $\mathrm{Ni} 2$ & $2 d$ & $1 / 3$ & $2 / 3$ & $1 / 4$ & $1.08(2)$ & 1 \\
\hline & $\mathrm{Ni3}$ & $2 a$ & 0 & 0 & $1 / 4$ & $4.7(5)$ & $0.42(4)$ \\
\hline & $\mathrm{Si}$ & $6 h$ & $0.1610(2)$ & $0.4437(2)$ & $1 / 4$ & $1.08(5)$ & 1 \\
\hline \multirow{7}{*}{$\mathrm{Ce}_{6} \mathrm{Co}_{1.63(10)} \mathrm{Si}_{3}$} & Ce1 & $6 h$ & $0.23737(9)$ & $0.22917(10)$ & $1 / 4$ & $2.01(3)$ & 1 \\
\hline & Ce2 & $6 h$ & $0.51972(7)$ & $0.14029(7)$ & $1 / 4$ & 1.02(2) & 1 \\
\hline & Co1 & $4 e$ & 0 & 0 & $0.07(2)$ & 2.8(13) & $0.07(2)$ \\
\hline & Co2 & $2 c$ & $1 / 3$ & $2 / 3$ & $1 / 4$ & $1.44(6)$ & 1 \\
\hline & Co3 & $2 a$ & 0 & 0 & $1 / 4$ & $2.1(10)$ & $0.21(4)$ \\
\hline & Co4 & $6 h$ & $0.061(2)$ & $0.061(2)$ & $1 / 4$ & $1.01(2)$ & $0.092(6)$ \\
\hline & $\mathrm{Si}$ & $6 h$ & $0.1599(4)$ & $0.4427(3)$ & $1 / 4$ & 1.18(10) & 1 \\
\hline \multirow{9}{*}{$\mathrm{Ce}_{5} \mathrm{Ni}_{1.851(9)} \mathrm{Si}_{3}$} & Ce1 & $6 h$ & $0.01060(2)$ & $0.18140(3)$ & $1 / 4$ & $1.413(9)$ & 1 \\
\hline & Ce2 & $6 h$ & $0.39891(2)$ & $0.26245(2)$ & $1 / 4$ & $0.808(8)$ & 1 \\
\hline & Ce3 & $6 h$ & $0.45462(2)$ & $0.06706(2)$ & $1 / 4$ & 0.794(8) & 1 \\
\hline & $\mathrm{Ce} 4$ & $2 d$ & $2 / 3$ & $1 / 3$ & $1 / 4$ & $0.775(8)$ & 1 \\
\hline & Ni1 & $6 h$ & $0.28238(5)$ & $0.49837(5)$ & $1 / 4$ & $0.87(2)$ & 1 \\
\hline & $\mathrm{Ni} 2$ & $2 b$ & 0 & 0 & 0 & $5.0(2)$ & 0.193(8) \\
\hline & $\mathrm{Ni3}$ & $2 a$ & 0 & 0 & $1 / 4$ & 5.0 & $0.509(10)$ \\
\hline & Si1 & $6 h$ & $0.16578(11)$ & $0.55041(11)$ & $1 / 4$ & $0.84(4)$ & 1 \\
\hline & $\mathrm{Si} 2$ & $6 h$ & $0.23288(12)$ & $0.32685(11)$ & $1 / 4$ & $0.92(4)$ & 1 \\
\hline
\end{tabular}


Table 3: Anisotropic displacement parameters of Ce1 position in the three ternary silicides

\begin{tabular}{lccccccc}
\hline & Atom & $\mathrm{U}^{11}$ & $\mathrm{U}^{22}$ & $\mathrm{U}^{33}$ & $\mathrm{U}^{12}$ & $\mathrm{U}^{13}$ & $\mathrm{U}^{23}$ \\
\hline $\mathbf{C e}_{6} \mathbf{N i}_{1.67} \mathrm{Si}_{3}$ & $\mathrm{Ce} 1$ & $0.0224(2)$ & $0.0291(2)$ & $0.0143(2)$ & $0.0187(2)$ & 0 & 0 \\
$\mathbf{C e}_{6} \mathbf{C o}_{1.67} \mathrm{Si}_{3}$ & & & & & & & \\
& Ce1 & $0.0329(5)$ & $0.0440(6)$ & $0.0144(3)$ & $0.0304(5)$ & 0 & 0 \\
$\mathbf{C e}_{5} \mathbf{N i}_{1.85} \mathrm{Si}_{3}$ & & & & & & & \\
& Ce1 & $0.01286(14)$ & $0.0282(2)$ & $0.01411(14)$ & $0.01138(13)$ & 0 & 0 \\
\hline
\end{tabular}


Table 4: Selected interatomic distances $(\AA \AA)$ in $\mathrm{Ce}_{6} \mathrm{Ni}_{1.67} \mathrm{Si}_{3}, \mathrm{Ce}_{6} \mathrm{Co}_{1.67} \mathrm{Si}_{3}$ and $\mathrm{Ce}_{5} \mathrm{Ni}_{1.85} \mathrm{Si}_{3}$

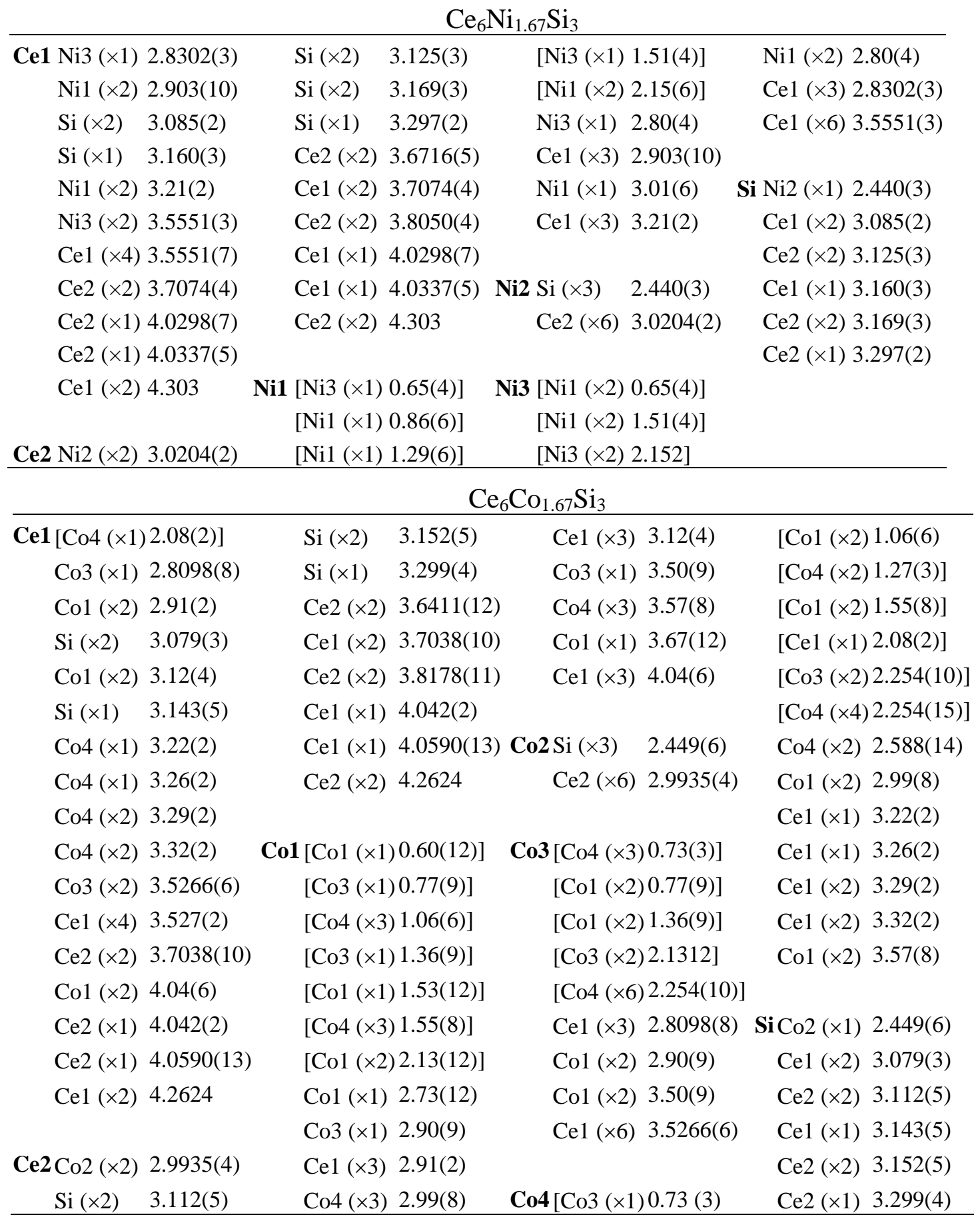


$\mathrm{Ce}_{5} \mathrm{Ni}_{1.85} \mathrm{Si}_{3}$

\begin{tabular}{|c|c|c|c|c|}
\hline Ce1 Ni3 (×1) 2.8217(5) & Ce4 $(\times 1)$ 3.8450(3) & Ce2 $(\times 3)$ & $3.8450(3)$ & $\mathrm{Ni} 2(\times 2) 3.2026$ \\
\hline Ni2 (×2) 3.0169(5) & Ce1 (×1) 4.0577(5) & Ce3 $(\times 3)$ & $3.9000(2)$ & Ce1 (×6) 3.5384(6) \\
\hline Si2 $(\times 2) \quad 3.068(2)$ & Ce3 $(\times 1) 4.0868(3)$ & Ce4 $(\times 2)$ & 4.2701 & \\
\hline $\mathrm{Si} 2(\times 1) \quad 3.1289(13)$ & $\mathrm{Ce} 2(\times 2) 4.2701$ & & & Si1 Ni1 (×1) 2.3782(14) \\
\hline Ce1 (×4) 3.5384(6) & & Ni1 Si1 (×1) & $2.3782(14)$ & Ni1 (×1) 2.393(2) \\
\hline $\mathrm{Ni3}(× 2) 3.5384(4)$ & Ce3 Ni1 (×2) 3.0099(8) & $\operatorname{Si} 1(\times 1)$ & $2.393(2)$ & Ce2 (×2) 3.0849(9) \\
\hline Ce2 $(\times 2) 3.7039(4)$ & Si1 (×2) 3.0998(13) & $\operatorname{Si} 2(\times 1)$ & $2.448(2)$ & Ce3 (×2) 3.0998(13) \\
\hline Ce2 (×1) 4.0577(5) & Si2 $(\times 2) \quad 3.131(2)$ & Ce2 $(\times 2)$ & $2.9711(8)$ & Ce4 $(\times 2) 3.197(2)$ \\
\hline Сe3 (×1) 4.0652(7) & Si1 $(\times 1) \quad 3.311(2)$ & Ce3 $(\times 2)$ & $3.0099(8)$ & Сe3 $(\times 1) 3.311(2)$ \\
\hline $\mathrm{Ni} 2(× 2) 4.2683(3)$ & Ce2 (×1) 3.6547(5) & Ce4 $(\times 2)$ & 3.2062(9) & \\
\hline \multirow[t]{2}{*}{ Ce1 $(\times 2) 4.2701$} & Ce3 (×2) 3.7934(5) & & & Si2 Ni1 (×1) 2.448(2) \\
\hline & Ce2 (×2) 3.8217(5) & Ni2 [Ni3 $(\times 2)$ & $1.0675]$ & Ce1 $(\times 2) 3.068(2)$ \\
\hline Ce2 Ni1 (×2) 2.9711(8) & Ce4 (×1) 3.9000(2) & {$[\mathrm{Ni} 2(\times 2)$} & $2.1351]$ & Ce1 (×1) 3.1289(13) \\
\hline Si1 (×2) $3.0849(9)$ & Ce1 (×1) 4.0652(7) & Ce1 $(\times 6)$ & $3.0169(5)$ & Се3 (×2) 3.131(2) \\
\hline Si2 (×2) 3.1705(15) & Ce2 (×1) 4.0868(3) & $\mathrm{Ni3}(\times 2)$ & 3.2026 & Ce2 (×2) 3.1705(15) \\
\hline Si2 (×1) $3.294(2)$ & Ce3 $(\times 2) 4.2701$ & & & Ce2 (×1) 3.294(2) \\
\hline Сe3 (×1) 3.6547(5) & & Ni3 $[\mathrm{Ni} 2(\times 2)$ & $1.0675]$ & \\
\hline Ce1 (×2) 3.7039(4) & Ce4 Si1 (×6) 3.197(2) & $\mathrm{Ni3}(\times 2)$ & 2.1351 & \\
\hline Ce3 $(\times 2) 3.8217(5)$ & Ni1 (×6) 3.2062(9) & Ce1 $(\times 3)$ & $2.8217(5)$ & \\
\hline
\end{tabular}

Distances listed in brackets involve partially occupied sites and do not need to occur. 
Figure captions

Fig. 1 X-ray powder patterns of "Ce${ }_{6} \mathrm{Ni}_{2} \mathrm{Si}_{3}$ " alloy obtained by melting (as-cast) or annealing. (o indicates the peak position for $\mathrm{Ce}_{7} \mathrm{Ni}_{3}$ ).

Fig. 2 Microstructure of "Ce${ }_{6} \mathrm{Ni}_{2} \mathrm{Si}_{3}$ " alloy obtained after melting and quenching. The two phases $\mathrm{Ce}_{6} \mathrm{Ni}_{1.67} \mathrm{Si}_{3}$ (grey) and $\mathrm{Ce}_{7} \mathrm{Ni}_{3}$ (white grey) are indicated.

Fig. 3 X-ray powder patterns of $\mathrm{Ce}_{6} \mathrm{Ni}_{1.67} \mathrm{Si}_{3}$ ternary silicide obtained by melting (as-cast) or annealing. (* indicates the peak position for $\mathrm{Ce}_{5} \mathrm{Si}_{3}$ ).

Fig. 4 Structural model of $\mathrm{Ce}_{6} \mathrm{Ni}_{1.67} \mathrm{Si}_{3}$ with anisotropic ADP for all positions: (left) yz section at $\mathrm{x}=0$ of Fourier map and (right) $x y$ section at $\mathrm{z}=1 / 4$ of difference-Fourier maps (contours with full line for positive values and dashed line for negative values in intervals of 2 e $\AA^{-3}$ for Fourier and 0.4 e $\AA^{-3}$ for difference-Fourier map. The filled circles correspond to the refined Ni positions.

Fig. 5 Joint probability density function maps of $\mathrm{Ni}$ for $\mathrm{Ce}_{6} \mathrm{Ni}_{1.67} \mathrm{Si}_{3}$ : (left) non-harmonic model, $y z$ section at $x=0$ and (right) non-harmonic model, $x y$ section at $z=1 / 4$ (positive (full lines) and negative (dashed lines) contours are drawn in intervals of 0.2 and $-0.2 \AA^{-3}$ ). The filled circles correspond to the refined Ni positions.

Fig. 6 Projections along the $c$ axis of the structure of (a) $\mathrm{Ce}_{6} \mathrm{Ni}_{1.67} \mathrm{Si}_{3}$, (b) $\mathrm{Ce}_{6} \mathrm{Co}_{1.67} \mathrm{Si}_{3}$ and (c) $\mathrm{Ce}_{5} \mathrm{Ni}_{1.85} \mathrm{Si}_{3}$. Ce and $\mathrm{Si}$ atoms are represented by large and small grey spheres, respectively, and Ni or Co atoms by black spheres.

Fig. 7 (left) $x y$ section at $z=1 / 4$ of the difference-Fourier map for $\mathrm{Ce}_{6} \mathrm{Co}_{1.67} \mathrm{Si}_{3}$ before the introduction of Co4 position (contour lines are in intervals of 1 (full lines) and -1 e $\AA^{-3}$ (dashed lines)) and (right) $y z$ section at $\mathrm{x}=0$ of the Fourier map for $\mathrm{Ce}_{6} \mathrm{Co}_{1.67} \mathrm{Si}_{3}$ after final refinement (contour lines are in intervals of 2 (full lines) and -2 e $\AA^{-3}$ (dashed lines)); the filled circles correspond to the refined Co positions.

Fig. $8 \mathrm{Ce}_{5} \mathrm{Ni}_{1.85} \mathrm{Si}_{3}: y z$ sections at $\mathrm{x}=0$ of the (left) Fourier map after final refinement (contour lines are in intervals of 2.5 (full lines) and -2.5 e $\AA^{-3}$ (dashed lines)), (middle) difference-Fourier map before introduction of $\mathrm{Ni} 2$ and $\mathrm{Ni} 3$ positions (contour lines are in intervals of 1 (full lines) and -1 e $\AA^{-3}$ (dashed lines)) and (right) joint probability maps of $\mathrm{Ni}$ after final refinement (contour lines are in intervals of $0.14 \AA^{-1}$ ). The filled circles correspond to the refined $\mathrm{Ni}$ positions.

Fig. 9 Temperature dependence of the reciprocal magnetic susceptibility of $\mathrm{Ce}_{6} \mathrm{Ni}_{1.67} \mathrm{Si}_{3}$ and $\mathrm{Ce}_{6} \mathrm{Co}_{1.67} \mathrm{Si}_{3}$. The dashed lines present the Curie-Weiss law. 
Fig. 10 Temperature dependence of the magnetization divided by applied field for : (a) $\mathrm{Ce}_{6} \mathrm{Co}_{1.67} \mathrm{Si}_{3}\left(\mu_{0} \mathrm{H}=1000 \mathrm{Oe}\right)$ and (b) $\mathrm{Ce}_{6} \mathrm{Ni}_{1.67} \mathrm{Si}_{3}\left(\mu_{0} \mathrm{H}=200\right.$ and $\left.1000 \mathrm{Oe}\right)$.

Fig. 11 Temperature dependence of the specific heat $\mathrm{C}_{\mathrm{p}}$ of $\mathrm{Ce}_{6} \mathrm{Co}_{1.67} \mathrm{Si}_{3}$ and $\mathrm{Ce}_{6} \mathrm{Ni}_{1.67} \mathrm{Si}_{3}$. The curve $\mathrm{C}_{\mathrm{p}} / \mathrm{T}=\mathrm{f}(\mathrm{T})$ for $\mathrm{Ce}_{6} \mathrm{Co}_{1.67} \mathrm{Si}_{3}$ is plotted in the inset.

Fig. 12 Temperature dependence of the magnetization divided by applied field for $\mathrm{Ce}_{5} \mathrm{Ni}_{1.85} \mathrm{Si}_{3}\left(\mu_{0} \mathrm{H}=200 \mathrm{Oe}\right)$. 


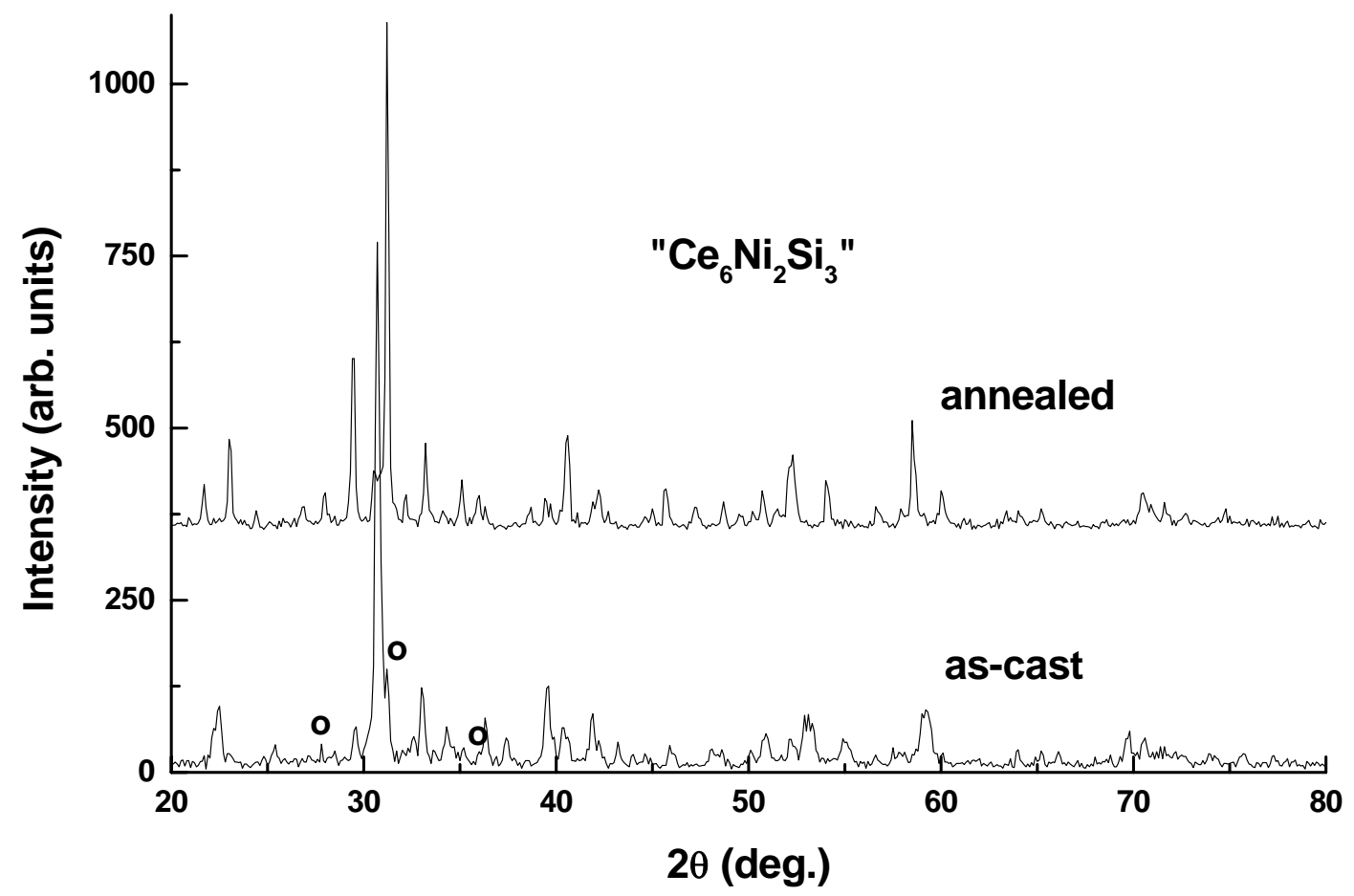

Fig. $1 \mathrm{X}$-ray powder patterns of "Ce${ }_{6} \mathrm{Ni}_{2} \mathrm{Si}_{3}$ " alloy obtained by melting (as-cast) or annealing. (o indicates the peak position for $\mathrm{Ce}_{7} \mathrm{Ni}_{3}$ ). 


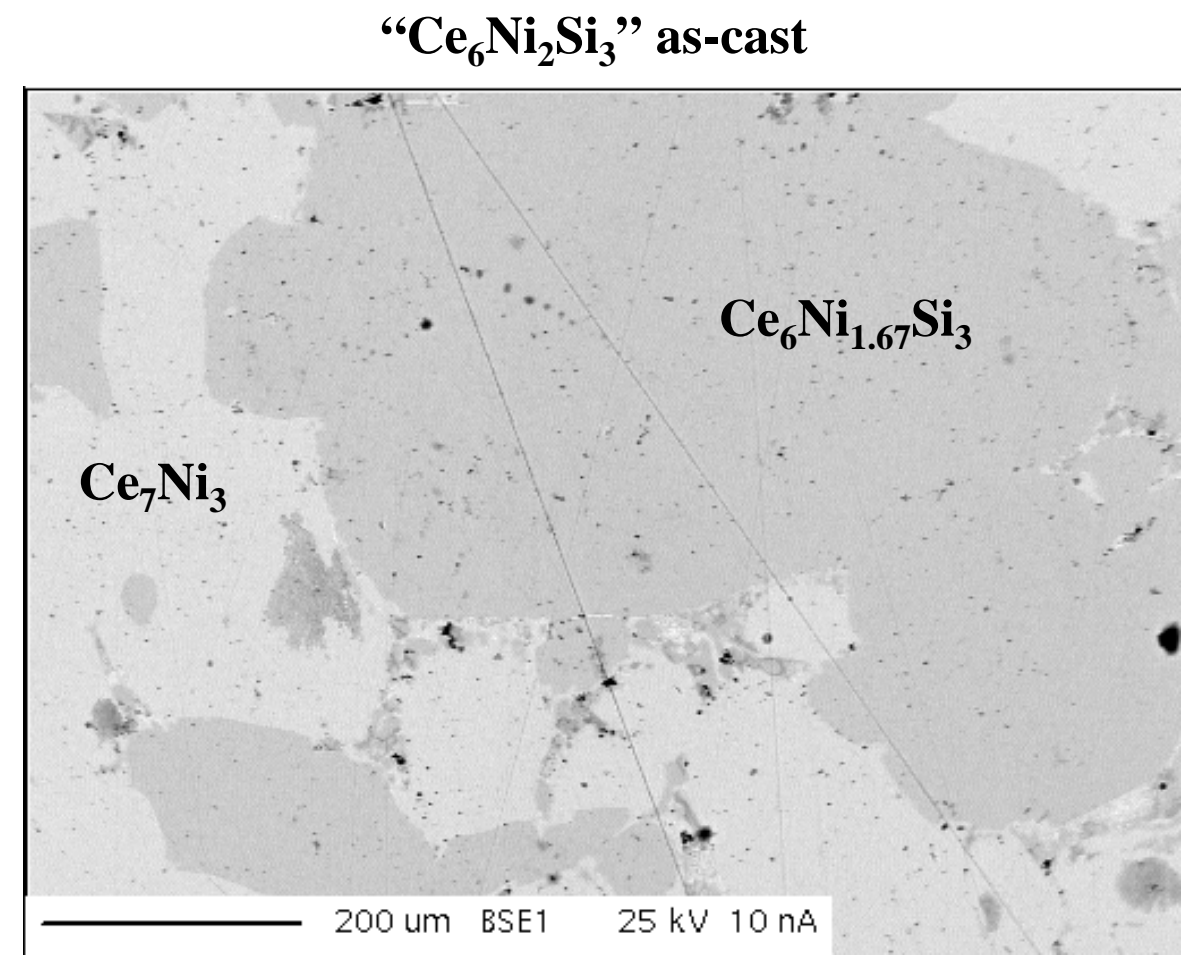

Fig. 2 Microstructure of "Ce${ }_{6} \mathrm{Ni}_{2} \mathrm{Si}_{3}$ " alloy obtained after melting and quenching. The two phases $\mathrm{Ce}_{6} \mathrm{Ni}_{1.67} \mathrm{Si}_{3}$ (grey) and $\mathrm{Ce}_{7} \mathrm{Ni}_{3}$ (white grey) are indicated. 


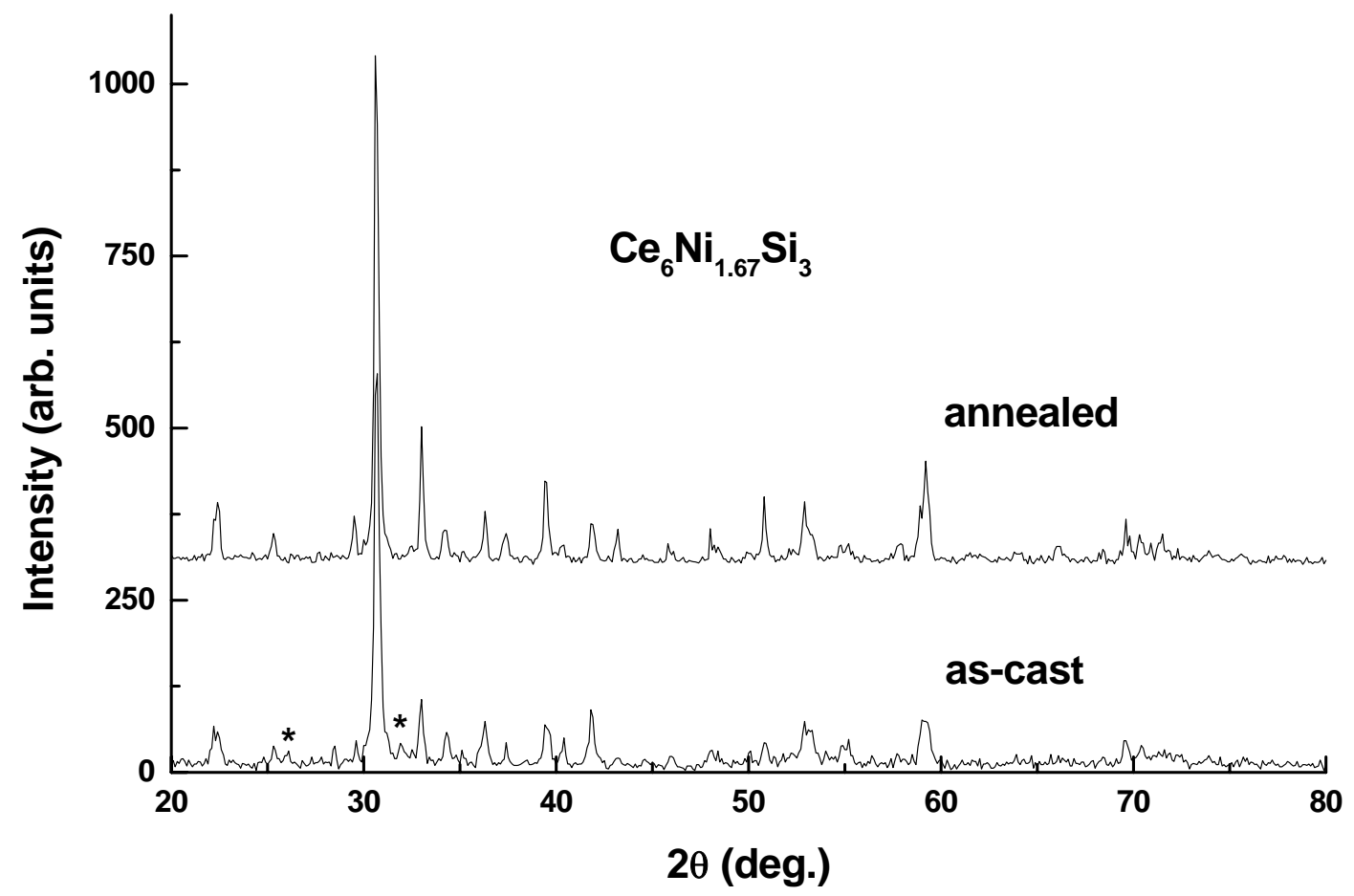

Fig. 3 X-ray powder patterns of $\mathrm{Ce}_{6} \mathrm{Ni}_{1.67} \mathrm{Si}_{3}$ ternary silicide obtained by melting (as-cast) or annealing. (* indicates the peak position for $\mathrm{Ce}_{5} \mathrm{Si}_{3}$ ). 

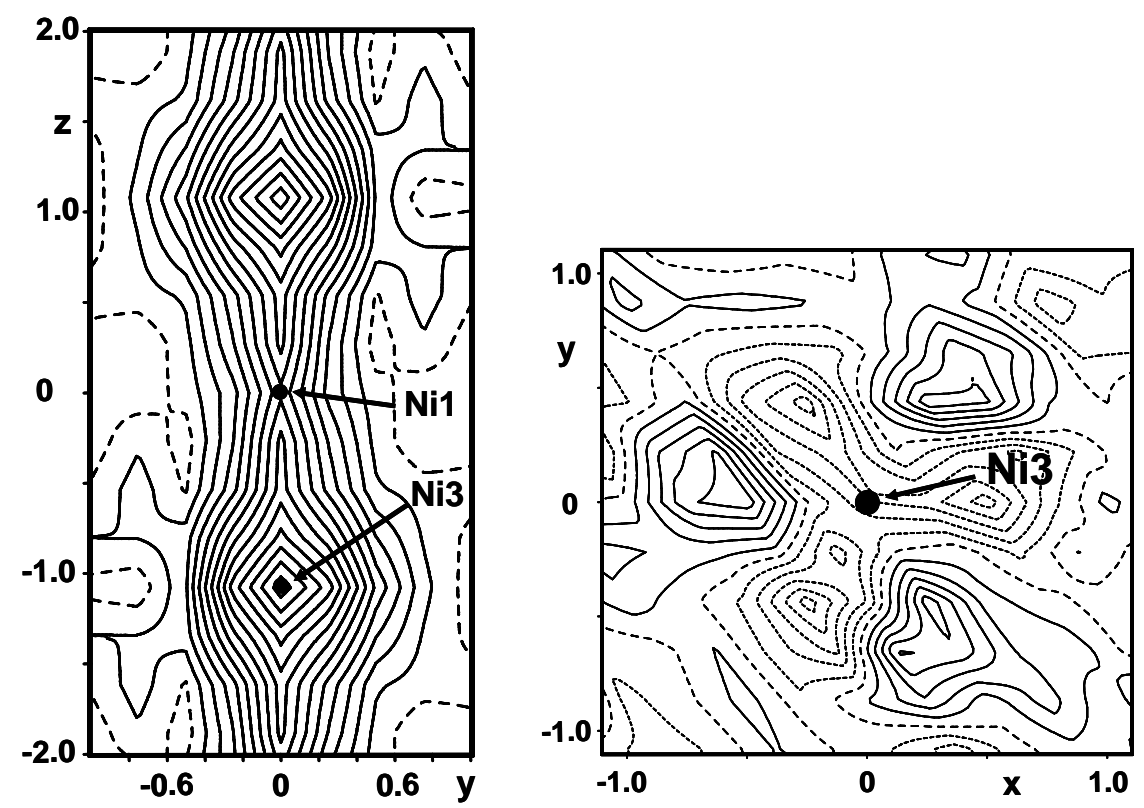

Fig. 4. Structural model of $\mathrm{Ce}_{6} \mathrm{Ni}_{1.67} \mathrm{Si}_{3}$ with anisotropic ADP for all positions: (left) $y z$ section at $\mathrm{x}=0$ of Fourier map and (right) $x y$ section at $\mathrm{z}=1 / 4$ of difference-Fourier maps (contours with full line for positive values and dashed line for negative values in intervals of 2 e $\AA^{-3}$ for Fourier and 0.4 e $\AA^{-3}$ for difference-Fourier map. The filled circles correspond to the refined $\mathrm{Ni}$ positions. 

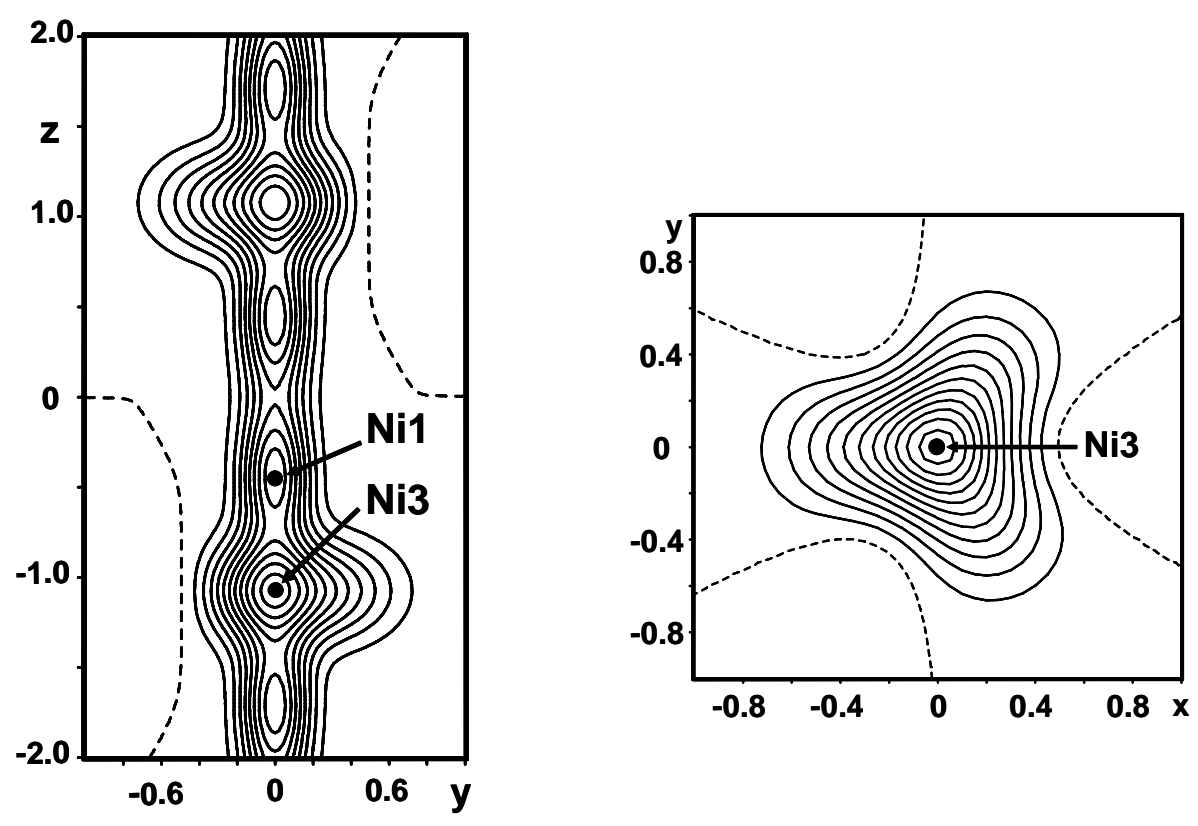

Fig. 5 Joint probability density function maps of $\mathrm{Ni}$ for $\mathrm{Ce}_{6} \mathrm{Ni}_{1.67} \mathrm{Si}_{3}$ : (left) non-harmonic model, $y z$ section at $x=0$ and (right) non-harmonic model, $x y$ section at $z=1 / 4$ (positive (full lines) and negative (dashed lines) contours are drawn in intervals of 0.2 and $-0.2 \AA^{-3}$ ). The filled circles correspond to the refined Ni positions. 
(a)

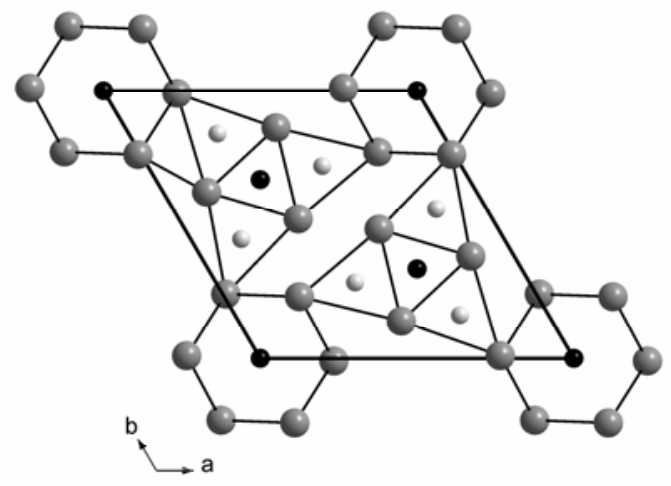

(b)

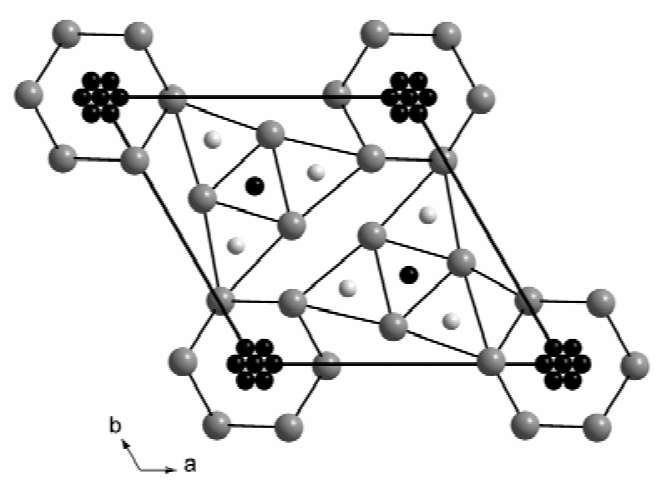

(c)

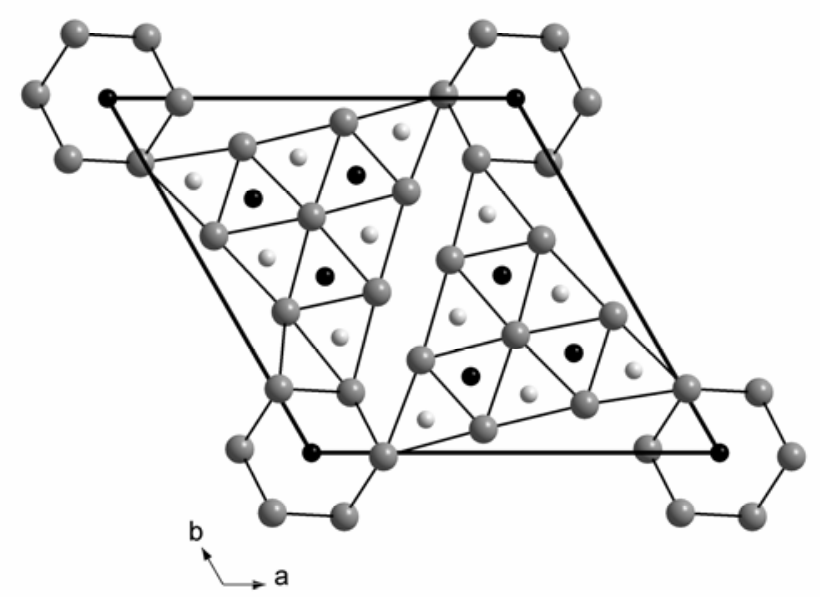

Fig. 6 Projections along the $c$ axis of the structure of (a) $\mathrm{Ce}_{6} \mathrm{Ni}_{1.67} \mathrm{Si}_{3}$, (b) $\mathrm{Ce}_{6} \mathrm{Co}_{1.67} \mathrm{Si}_{3}$ and (c) $\mathrm{Ce}_{5} \mathrm{Ni}_{1.85} \mathrm{Si}_{3}$. Ce and $\mathrm{Si}$ atoms are represented by large and small grey spheres, respectively, and $\mathrm{Ni}$ or $\mathrm{Co}$ atoms by black spheres. 

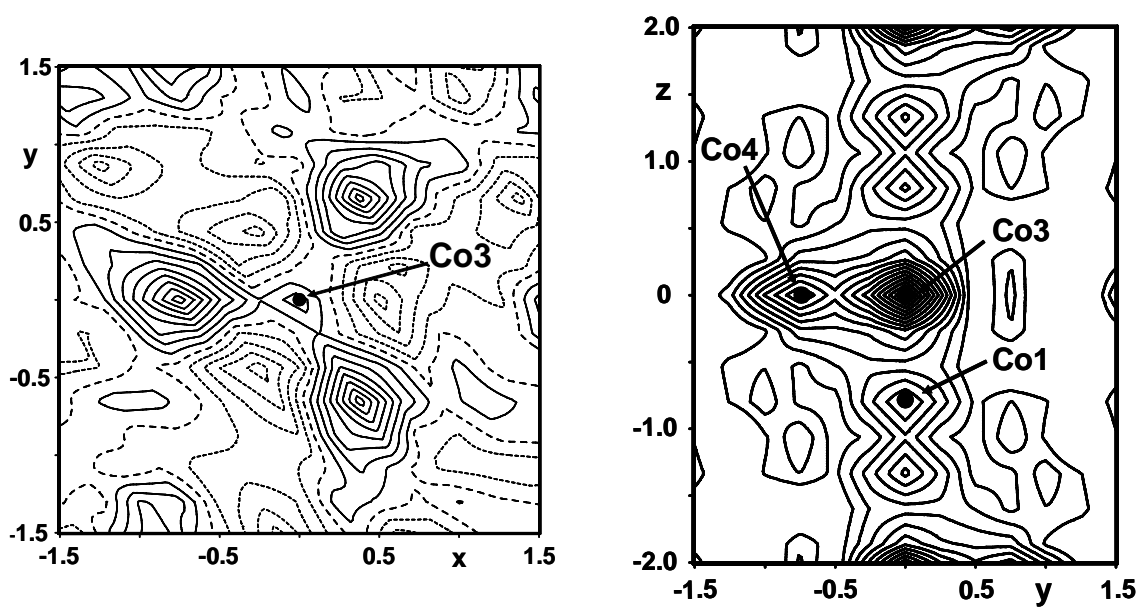

Fig. 7 (left) $x y$ section at $z=1 / 4$ of the difference-Fourier map for $\mathrm{Ce}_{6} \mathrm{Co}_{1.67} \mathrm{Si}_{3}$ before the introduction of Co4 position (contour lines are in intervals of 1 (full lines) and -1 e $\AA^{-3}$ (dashed lines)) and (right) $y z$ section at $\mathrm{x}=0$ of the Fourier map for $\mathrm{Ce}_{6} \mathrm{Co}_{1.67} \mathrm{Si}_{3}$ after final refinement (contour lines are in intervals of 2 (full lines) and -2 e $\AA^{-3}$ (dashed lines)); the filled circles correspond to the refined Co positions. 

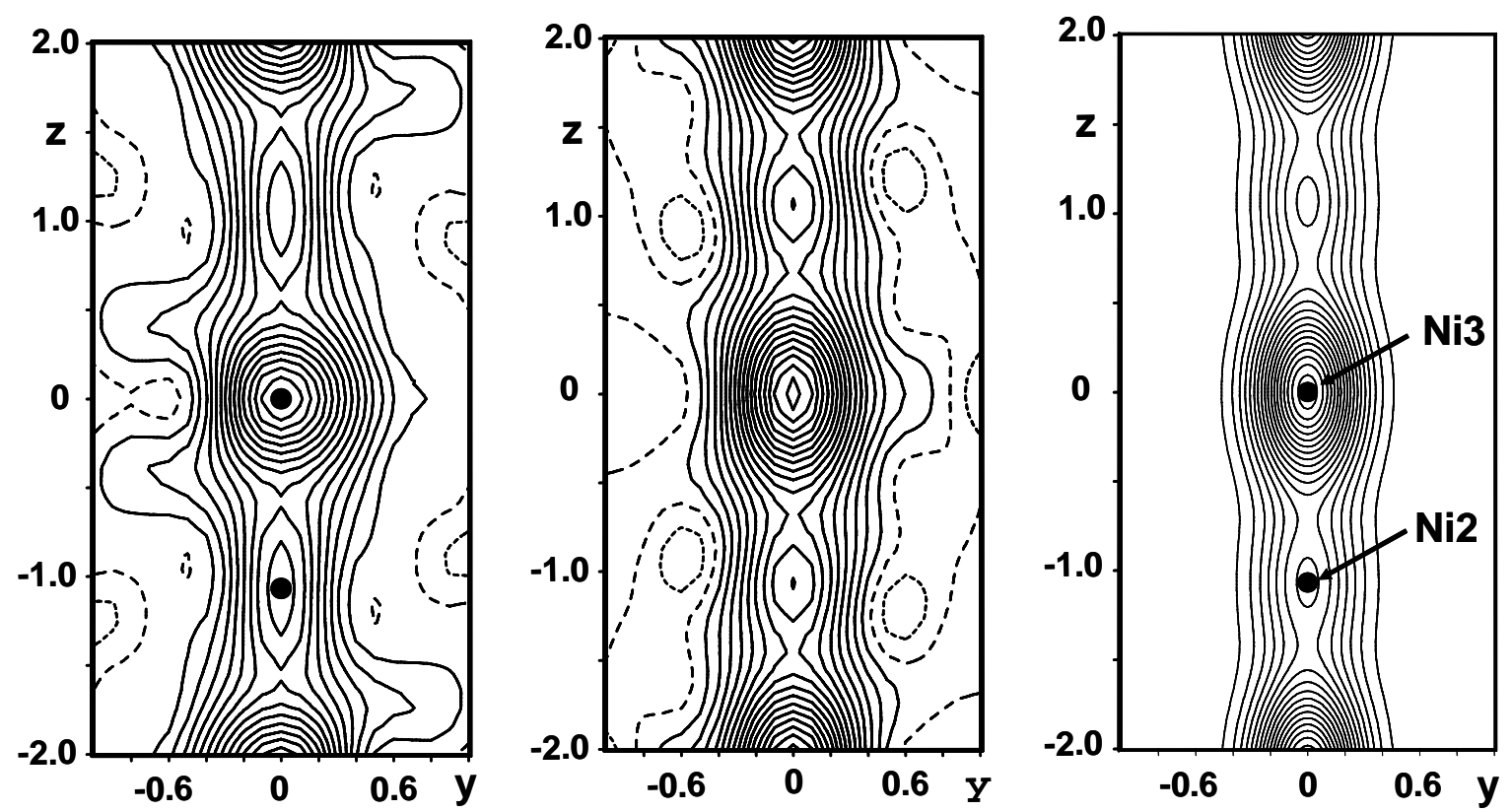

Fig. $8 \mathrm{Ce}_{5} \mathrm{Ni}_{1.85} \mathrm{Si}_{3}: y z$ sections at $\mathrm{x}=0$ of the (left) Fourier map after final refinement (contour lines are in intervals of 2.5 (full lines) and -2.5 e $\AA^{-3}$ (dashed lines)), (middle) difference-Fourier map before introduction of $\mathrm{Ni} 2$ and $\mathrm{Ni3}$ positions (contour lines are in intervals of 1 (full lines) and -1 e $\AA^{-3}$ (dashed lines)) and (right) joint probability maps of Ni after final refinement (contour lines are in intervals of $0.14 \AA^{-1}$ ). The filled circles correspond to the refined Ni positions. 


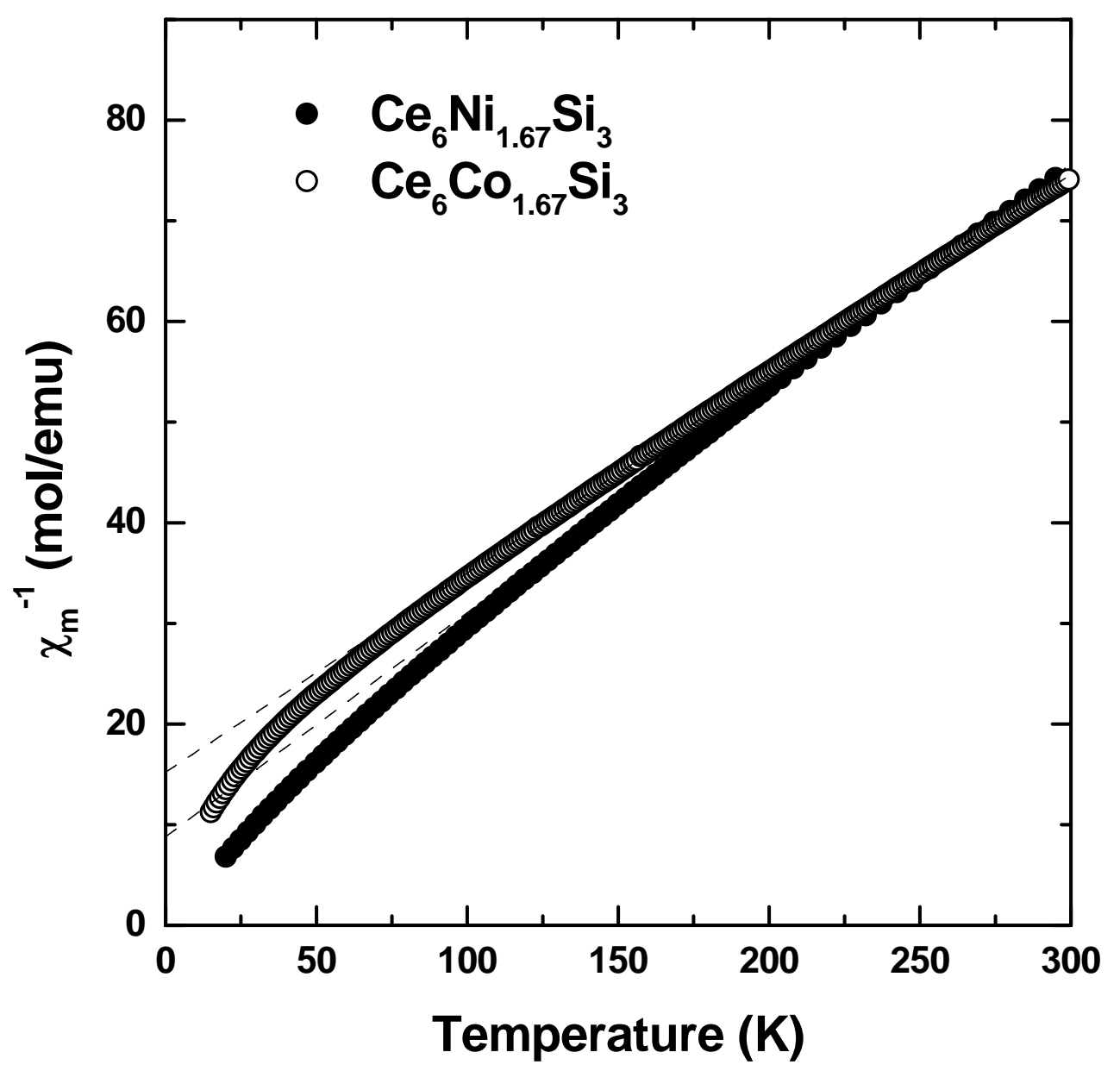

Fig. 9 Temperature dependence of the reciprocal magnetic susceptibility of $\mathrm{Ce}_{6} \mathrm{Ni}_{1.67} \mathrm{Si}_{3}$ and $\mathrm{Ce}_{6} \mathrm{Co}_{1.67} \mathrm{Si}_{3}$. The dashed lines present the Curie-Weiss law. 

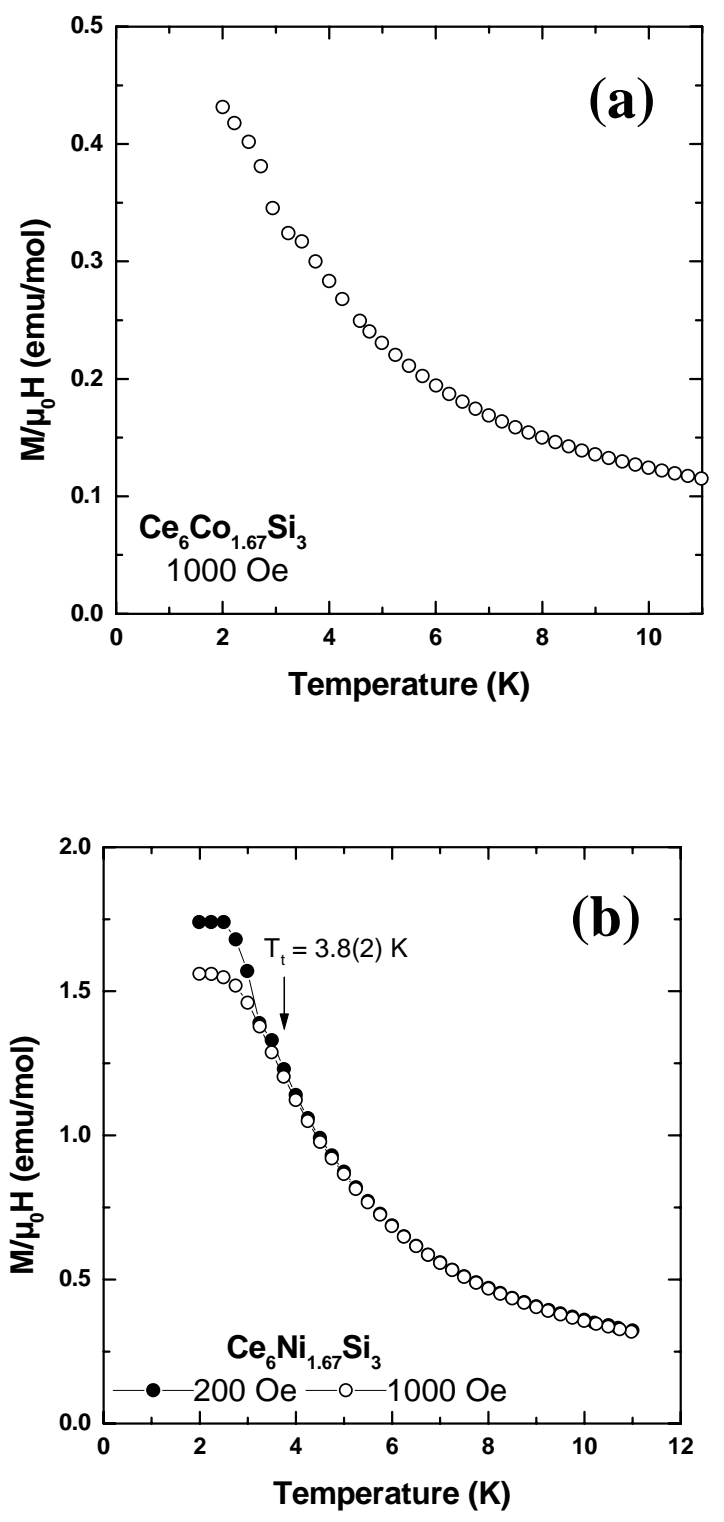

Fig. 10 Temperature dependence of the magnetization divided by applied field for : (a) $\mathrm{Ce}_{6} \mathrm{Co}_{1.67} \mathrm{Si}_{3}\left(\mu_{0} \mathrm{H}=1000 \mathrm{Oe}\right)$ and (b) $\mathrm{Ce}_{6} \mathrm{Ni}_{1.67} \mathrm{Si}_{3}\left(\mu_{0} \mathrm{H}=200\right.$ and $\left.1000 \mathrm{Oe}\right)$. 


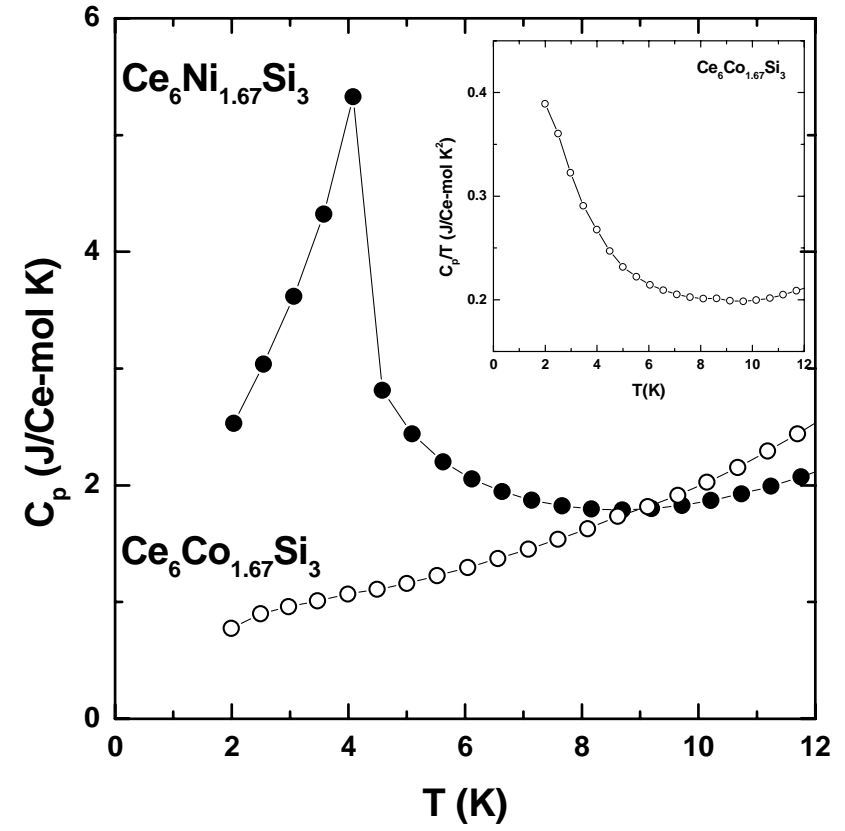

Fig. 11 Temperature dependence of the specific heat $\mathrm{C}_{\mathrm{p}}$ of $\mathrm{Ce}_{6} \mathrm{Co}_{1.67} \mathrm{Si}_{3}$ and $\mathrm{Ce}_{6} \mathrm{Ni}_{1.67} \mathrm{Si}_{3}$. The curve $\mathrm{C}_{\mathrm{p}} / \mathrm{T}=\mathrm{f}(\mathrm{T})$ for $\mathrm{Ce}_{6} \mathrm{Co}_{1.67} \mathrm{Si}_{3}$ is plotted in the inset. 


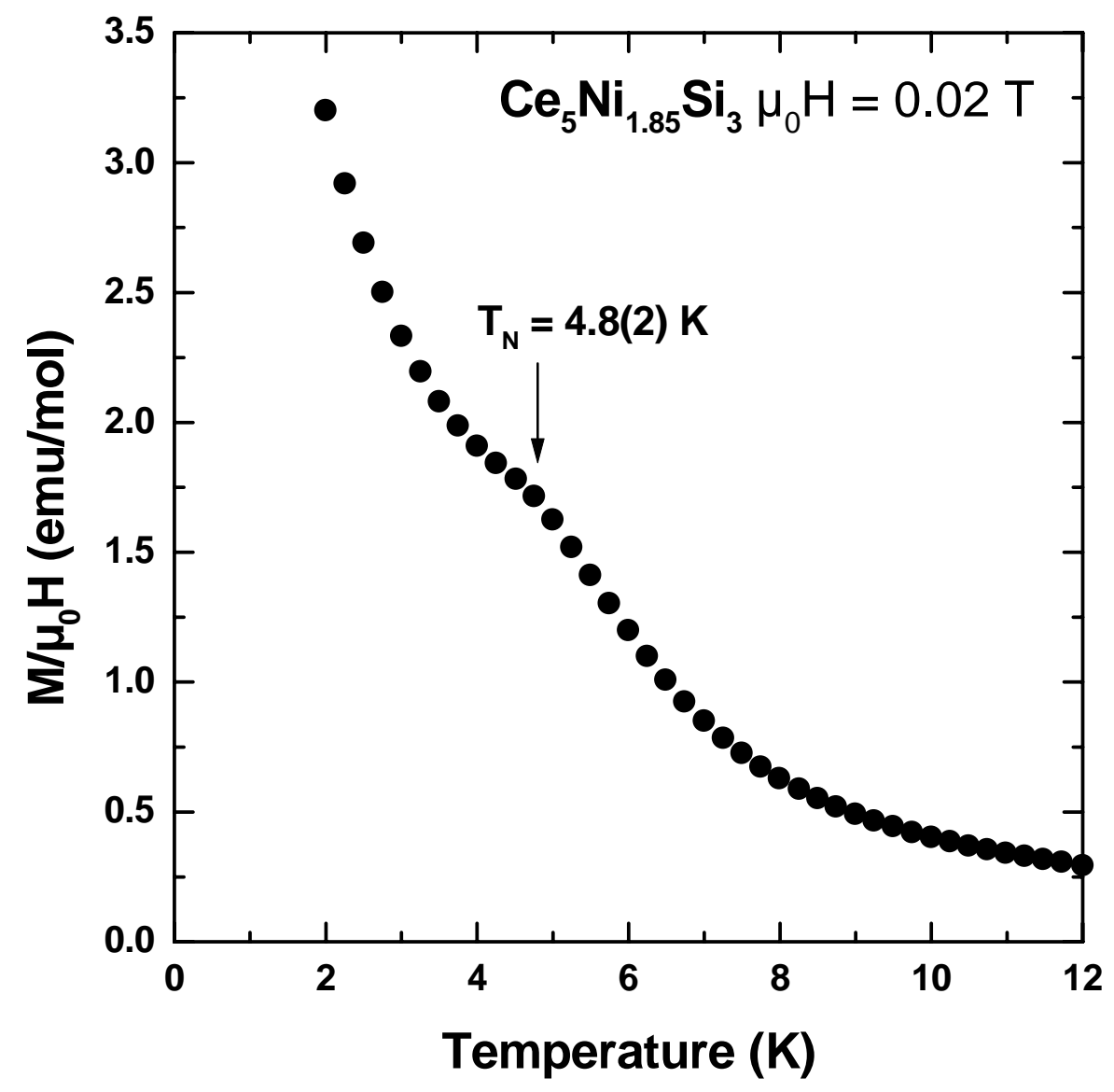

Fig. 12 Temperature dependence of the magnetization divided by applied field for $\mathrm{Ce}_{5} \mathrm{Ni}_{1.85} \mathrm{Si}_{3}\left(\mu_{0} \mathrm{H}=200 \mathrm{Oe}\right)$. 